\title{
Correlations of Morphological, Anatomical, and Chemical Features of Grape Berries with Resistance to Botrytis cinerea
}

\author{
Franka Mlikota Gabler, Joseph L. Smilanick, Monir Mansour, David W. Ramming, and Bruce E. Mackey
}

First author: Institute for Adriatic Crops, Put Duilova 11, 21000 Split, Croatia; second and fourth authors: U.S. Department of AgricultureAgricultural Research Service (USDA-ARS), Horticultural Crops Research Laboratory, San Joaquin Valley Agricultural Sciences Center, 9611 South Riverbend Ave., Parlier, CA 93648; third author: Department of Horticulture, Menofiya University, Shebin El-Kom, Egypt; and fifth author: Biometrical Services, USDA-ARS, Western Regional Research Center, 800 Buchanan Street, Albany, CA 94710.

Current address of F. Mlikota Gabler and M. Mansour: USDA-ARS, Horticultural Crops Research Laboratory, San Joaquin Valley Agricultural Sciences Center, 9611 South Riverbend Ave., Parlier, CA 93648.

Accepted for publication 21 April 2003.

\begin{abstract}
Mlikota Gabler, F., Smilanick, J. L., Mansour, M., Ramming, D. W., and Mackey, B. E. 2003. Correlations of morphological, anatomical, and chemical features of grape berries with resistance to Botrytis cinerea. Phytopathology 93:1263-1273.

Resistance of mature berries of grapevine cultivars and selections to postharvest infection by Botrytis cinerea was assessed. Little or no resistance existed in most popular table grape Vitis vinifera cultivars, except in moderately resistant 'Emperor' and 'Autumn Black'. Highly resistant grapes were V. rotundifolia, V. labrusca, or other complex hybrids. Morphological, anatomical, and chemical characteristics of 42 genetically diverse cultivars and selections with various levels of resistance to $B$. cinerea were examined to determine which features were associated with

resistance. We quantified the (i) density of berries within a cluster; (ii) number of pores and lenticels on the berry surface; (iii) thickness and number of cell layers in the epidermis and external hypodermis; (iv) amount of cuticle and wax; (v) berry skin protein content; (vi) total phenolic content of the skin before and after $B$. cinerea inoculation; and (vii) catechin and trans- and cis-resveratrol contents of the skin before and after inoculation. The number of pores was negatively correlated with resistance. Highly resistant cultivars had few or no pores in the berry surface. The number and thickness of epidermal and hypodermal cell layers and cuticle and wax contents were positively correlated with resistance. Other characteristics evaluated were not associated with resistance. trans-Resveratrol and cis-resveratrol were induced by $B$. cinerea inoculation only in sensitive and moderately resistant cultivars and selections.
\end{abstract}

Gray mold, caused by Botrytis cinerea Pers., causes pre- and postharvest decay of grapes during cold storage. It is the most economically important postharvest disease of table grapes (8). In a 1999 industry survey (California Table Grape Commission, unpublished data), $92 \%$ of table grape growers in California described the problem of gray mold as very important $(64 \%)$ or important (28\%). Currently, gray mold is controlled before harvest by canopy management and fungicide applications (32) and after harvest by sulfur dioxide fumigation (31). Gray mold is especially troublesome in cold storage because it develops at cold temperatures $\left(-0.5^{\circ} \mathrm{C}\right)$, rapidly spreads among berries, and grows vigorously.

Many researchers $(14,22,27,36,48)$ have stated the advantages of breeding resistant cultivars as a method of controlling gray mold. Better knowledge of interactions between host and pathogen will help achieve more accurate and successful resistance engineering strategies (16). Knowledge of the mode of resistance would lead to more precise breeding, in which breeding goals could be achieved with greater speed $(15,19)$.

Factors contributing to disease resistance are constitutive (i.e., preformed) or induced. Constitutive elements include morphological or anatomical barriers, and some antifungal chemical constituents. Other chemical constituents, such as phytoalexins and

Corresponding author: J. L. Smilanick

E-mail address: jsmilanick@fresno.ars.usda.gov

Publication no. P-2003-0806-01R

This article is in the public domain and not copyrightable. It may be freely reprinted with customary crediting of the source. The American Phytopathological Society, 2003. pathogenesis-related (PR) proteins, are induced by stress or infection $(12,23,43,46)$. Among morphological and anatomical features of grapes associated with resistance are the thickness of the berry skin and the number of skin cell layers $(26,47)$, the density of cells in the skin $(41,47)$, the thickness of the berry cuticle and the wax content $(10,20,33,38,45)$, the density of the berries within a cluster $(38,53)$, and the number of pores or microscopic tears in the skin of the berry $(5,15)$. If some morphological feature is consistently associated with resistance, then selection of cultivars with some degree of gray mold resistance would be facilitated. Some preformed antifungal constituents of berries, like tannins and phenolic compounds, were reported to be important for resistance to gray mold $(18,35,36,47)$. Defense reactions by grapevine to $B$. cinerea infection include synthesis of phytoalexins, mainly stilbenes such as trans- and cis-resveratrol, $\alpha$ - and $\varepsilon$-viniferin, and pterostilbene $(1,11,14,24,29,45)$, and the synthesis of PR proteins, including chitinase, grape osmotin, $\beta$-1,3-glucanase, phenylalanine ammonialyase, and stilbene synthase $(4,12,30,43,46)$.

Most researchers conclude that $B$. cinerea resistance in grape berries is the result of many combined resources and cannot be ascribed to a single feature $(23,35,45)$. Previously, most studies of resistance to $B$. cinerea concerned either chemical or morphological and anatomical aspects of Vitis spp., with the exception of Sarig et al. (47), who compared physiological and anatomical features of the berries of five grapevine cultivars.

The objectives of this research were to identify and quantify the resistance of mature grape berries to $B$. cinerea infection within a diverse collection of grapevine cultivars in order to identify factors associated with resistance and to establish some morphological, anatomical, or physiological criteria to better comprehend the resistance process to facilitate in grapevine breeding. 


\section{MATERIALS AND METHODS}

Grapevine cultivars and selections were located in a U.S. Department of Agriculture-Agricultural Research Service vineyard in Fresno, California, which serves as a bank of material for a cultivar development program. Selections are the products of grapevine crosses that have been retained for further assessment. No fungicide or gibberellin treatments were applied prior to harvest, and the grapevines were not girdled.

Resistance to gray mold. Mature clusters from several grapevines were harvested. Only grapes with soluble solids content of $16 \%$ or higher were included in tests. The soluble solids content of the berries was determined by refractometer prior to resistance tests using the randomly selected berries. Healthy berries, with pedicel attached, were cut from the cluster rachis, pooled together, and randomized. Conidia of $B$. cinerea strain BCG8 were cultured on potato dextrose agar for 2 weeks at $20^{\circ} \mathrm{C}$, and conidia were rubbed from the surface of the agar with a sterile glass rod in a small volume of sterile water and adjusted to concentrations of 0 , $1.25 \times 10^{4}, 1.25 \times 10^{5}$, and $2.50 \times 10^{5}$ conidia per $\mathrm{ml}$ with a hemacytometer. The conidia were applied with an airbrush sprayer until run-off to detached berries in three replicates of 30 berries each, which were then placed in humidified boxes and stored for 6 days at $15^{\circ} \mathrm{C}$. After storage, the number of infected berries was counted, and inoculum concentration $\left(\mathrm{IC}_{50}\right)$, that is concentration of conidia that caused half of the berries to become infected, was estimated by regression. Seven or eight cultivars or selections (also referred to as entries) were included in each test. The very susceptible cv. Thompson Seedless was used in each test as a standard to which others were compared. A resistance factor $(\mathrm{R}$ factor) was calculated, which equaled the $\mathrm{IC}_{50}$ of the test cultivar divided by the $\mathrm{IC}_{50}$ of 'Thompson Seedless'. The $\mathrm{R}$ factor was determined in one or more tests conducted with each entry, and the mean value was calculated. Susceptible entries were tested in one or more seasons, and putative gray mold-resistant entries were retested in two or more seasons. A total of 102 entries were tested over 4 years and their resistance to $B$. cinerea was evaluated. The berries of 42 genetically diverse entries, for which gray mold resistance levels were consistent, were used to investigate morphological, anatomical, and chemical characteristics that could be associated with resistance or susceptibility to gray mold. Twentysix entries were examined in 2000. In 2001, we included all those from 2000, except C77-107, which was not available, and enlarged the sample with additional entries to 41 . The total number of entries examined in both years was 42 .

Density of berries within a cluster. Cluster density is the spatial arrangement of berries within a cluster. A cluster is considered loose if the berries are separate from one another so that air circulates easily among them. Compact clusters have berries with short pedicels attached to short lateral branches, and the

TABLE 1. Delivery program of a linear gradient of solvent A ( $2 \%$ glacial acetic acid) and solvent B ( $80 \%$ acetonitrile plus $0.4 \%$ glacial acetic acid) in high-performance liquid chromatography analysis of catechin and trans- and cis-resveratrol

\begin{tabular}{lcc}
\hline Time $(\mathrm{min})$ & \% Solvent A & \% Solvent B \\
\hline 0.00 & 100 & 0 \\
3.00 & 100 & 0 \\
6.00 & 96 & 4 \\
15.00 & 90 & 10 \\
30.00 & 85 & 15 \\
50.00 & 77 & 23 \\
60.00 & 75 & 25 \\
66.00 & 70 & 30 \\
80.00 & 50 & 50 \\
83.00 & 20 & 80 \\
85.00 & 100 & 0 \\
105.00 & 100 & 0 \\
110.00 & 100 & 0 \\
\hline
\end{tabular}

berries are pressed tightly against each other. Visual assessment was made at harvest in 2001 according to the following scale: $1=$ very loose, 3 = loose, 5 = medium loose (typically desirable), $7=$ tight, and $9=$ very tight. Values are the means of observations of a minimum of 10 clusters on two or more grapevines.

Thickness and number of cell layers in the epidermis and external hypodermis of the berry. A 2-mm-wide cross section from the central part of the berry was immersed for $1 \mathrm{~min}$ in a solution containing $50 \%$ of $0.1 \%$ cellufluor stain (Sigma Chemical, St. Louis) and 50\% $0.2 \mathrm{M}$ phosphate buffer ( $\mathrm{pH}$ 7.2) and immediately examined with an epifluorescent microscope (Leitz Dialux 22; Leitz, Wetzler, Germany; 450 to $490 \mathrm{~nm}$ excitation, $\times 400$ magnification). A digital image was captured and saved for analysis with NIH Image software. The number of cell layers in the epidermis and external hypodermis was counted and their thickness was measured. Six berries per entry were examined. One reading on either side of each section was recorded.

Number of lenticels and pores. Whole berries were immersed for $5 \mathrm{~min}$ in $10 \%$ fluorescein, sodium salt, and rinsed for $30 \mathrm{~s}$ in deionized water, and four 50- $\mathrm{mm}^{2}$-round disks were cut from four sides of each berry. The disks were examined by UV epifluorescent microscopy (Leitz Dialux 22; 340 to $380 \mathrm{~nm}$ excitation, $\times 40$ magnification), and the numbers of pores and lenticels per disk were recorded. Ten berries were examined per each entry in each of two seasons.

Cuticle and wax quantification. The methods of Baker and Bateman (2) and Percival et al. (38) were used to quantify the wax and cuticle amount of grape berries. Fifty berries were selected from the middle portion of the clusters and kept frozen at $-20^{\circ} \mathrm{C}$ until analyzed. Several epidermal disks, $5 \mathrm{~mm}$ in diameter, were cut with a cork borer from different parts of each berry. The cuticle and wax contents of three replicates, each containing 50 disks, were determined. Cuticle and wax layers were separated from underlying tissues by soaking the disks for $24 \mathrm{~h}$ at $30^{\circ} \mathrm{C}$ in $2.5 \mathrm{ml}$ of a digestion solution containing $0.5 \%$ cellulase (Sigma Chemical) and $0.1 \%$ pectinase (Sigma Chemical) dissolved in $0.1 \mathrm{M}$ sodium acetate buffer $(\mathrm{pH} 4)$. The disks of digestionresistant material (cuticle plus epicuticular wax) were collected on a metal screen and rinsed with deionized water until clean. The disks were air-dried and the epicuticular wax was dissolved by immersion of the disks in $2 \mathrm{ml}$ of $100 \%$ chloroform for $24 \mathrm{~h}$ to separate it from the cuticle. The wax dissolved in chloroform was transferred to preweighed beakers. Separate beakers containing either cuticle or wax were placed in an oven at $100^{\circ} \mathrm{C}$ for $24 \mathrm{~h}$ and their weights were recorded.

Berry skin chemical characterization. In 2000, grapes of 26 entries, for which resistance levels were consistent, were handharvested when mature ( 15 to $25 \%$ soluble solids). Total phenolic compound, resveratrol, and catechin contents were measured in the skin of healthy berries that were not previously inoculated with $B$. cinerea and in berries induced by inoculation with the pathogen before the skin was removed. The induction procedure consisted of spraying small clusters with $1.25 \times 10^{4}$ conidia per ml of $B$. cinerea and their incubation in humidified boxes at $15^{\circ} \mathrm{C}$ for 2 days prior to removal of the berry skins. Noninoculated clusters were similarly stored. Skins from 50 berries, inoculated and noninoculated, were removed by hand in a nitrogen atmosphere. Liquid nitrogen was added to the berry skins which were ground to a powder with a porcelain mortar and pestle and kept frozen at $-20^{\circ} \mathrm{C}$ until analyzed.

Protein content was assessed by a bicinchoninic acid protein assay (BCA Protein Assay Kit; Pierce, Rockford, IL). Frozen berry skin powder ( 0.1 to $0.2 \mathrm{~g}$ ) was homogenized in $1.0 \mathrm{ml}$ of Tris- $\mathrm{HCl}$ using a high-speed homogenizer and then transferred to microcentrifuge tubes and kept on ice until centrifuged for 5 min at $13,000 \times g$. To the supernatant, $100 \mu \mathrm{l}$ of deoxycholate was added. After $10 \mathrm{~min}, 100 \mu \mathrm{l}$ of trichloroacetic acid was added. Thirty minutes later, the samples were centrifuged for $5 \mathrm{~min}$ at 
$13,000 \times g$. The protein-containing pellet was suspended in $0.5 \mathrm{ml}$ of deionized water, $0.1 \mathrm{ml}$ of the solution was placed into $0.9 \mathrm{ml}$ of water, and then $2.0 \mathrm{ml}$ of BCA reagent mixture was added. The solution was mixed well, incubated for $30 \mathrm{~min}$ at $37^{\circ} \mathrm{C}$, and cooled. Absorbance was determined with a spectrophotometer (Model 340; Sequoia-Turner, Mountain View, CA) at $562 \mathrm{~nm}$. The total protein content was calculated using a formula from a standard curve prepared using bovine serum albumin.

Phenolic content was determined by adding $0.5 \mathrm{~g}$ of frozen berry skin powder to $6 \mathrm{ml}$ of methanol, and the mixture was macerated in a high-speed homogenizer and centrifuged at $8,000 \times g$ for 10 min. The pellet was extracted two more times with $6 \mathrm{ml}$ of methanol each time. The three supernatants were pooled and reduced to $\approx 10 \%$ of the original volume with a rotary evaporator. The concentrated extract was diluted to a volume of $10 \mathrm{ml}$ with deionized water and kept frozen at $-20^{\circ} \mathrm{C}$ until analyzed. Total phenolic content was determined using Folin-Ciocalteau reagent (50). Fifty microliters of Folin-Ciocalteau reagent was added to a $550-\mu \mathrm{l}$ sample and $350 \mu \mathrm{l}$ of $1 \mathrm{M} \mathrm{Na}_{2} \mathrm{CO}_{3}$ was added 2 min later. After $2 \mathrm{~h}$, the absorbance at $765 \mathrm{~nm}$ was recorded. Total phenols were calculated using the formula from a standard curve prepared using gallic acid (Sigma Chemical).

Catechin and cis- and trans-resveratrol content was measured. Frozen berry skin powder ( 4 to $6 \mathrm{~g}$ ) was added to $25 \mathrm{ml}$ of $100 \%$ ethanol, macerated in a high-speed homogenizer, and centrifuged at $8,000 \times g$ for $10 \mathrm{~min}$. The pellet was extracted two more times with $25 \mathrm{ml}$ of ethanol each time. The three supernatants were pooled and reduced to $\approx 5 \%$ of the original volume with a rotary evaporator. The concentrated extract was diluted to $10 \mathrm{ml}$ in ethanol and kept at $-20^{\circ} \mathrm{C}$ until analyzed. Catechin and trans-resveratrol were obtained from Sigma Chemical. cis-Resveratrol was prepared by UV irradiation of trans-resveratrol for $1 \mathrm{~h}$. Compounds were identi-

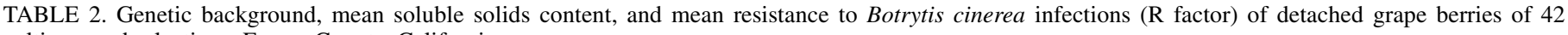
cultivars and selections, Fresno County, California

\begin{tabular}{|c|c|c|c|c|}
\hline Cultivar & Genetic background (Vitis) & Number of tests & Mean soluble solids (\%) & Mean R factor \\
\hline \multicolumn{5}{|l|}{ Highly susceptible } \\
\hline Baroque 11-8-58 & V. vinifera $\mathrm{L}$. & 1 & 23.5 & 0.1 \\
\hline Flame Seedless & $V$. vinifera $\mathrm{L}$. & 2 & 21.0 & 0.1 \\
\hline C94-71 & $V$. vinifera $\mathrm{L}$. & 1 & 23.5 & 0.1 \\
\hline A61-16 & $V$. vinifera $\mathrm{L}$. & 2 & 19.0 & 0.2 \\
\hline \multirow[t]{2}{*}{ B1479-1 } & $\begin{array}{l}\text { V. riparia } \text { Michx, V. labrusca } \mathrm{L} ., \text { V. cinerea } \text { Engelm., } \\
\text { V. rupestris Scheele, V. lincecumii Buckl., V. vinifera L., }\end{array}$ & & & \\
\hline & V. berlandieri Planch. & 1 & 25.5 & 0.2 \\
\hline C89-44 & V. vinifera $\mathrm{L}$. & 1 & 23.3 & 0.4 \\
\hline Autumn Royal & $V$. vinifera $\mathrm{L}$. & 1 & 21.5 & 0.7 \\
\hline Ruby Seedless & $V$. vinifera $\mathrm{L}$. & 2 & 20.5 & 0.8 \\
\hline C77-107 & $V$. vinifera $\mathrm{L}$. & 2 & 21.4 & 0.9 \\
\hline Thompson Seedless & $V$. vinifera $\mathrm{L}$. & 31 & 19.0 & 1.0 \\
\hline Queen & $V$. vinifera $\mathrm{L}$. & 2 & 20.8 & 1.0 \\
\hline B34-82 & $V$. vinifera $\mathrm{L}$. & 2 & 22.0 & 1.1 \\
\hline A59-91 & $V$. vinifera $\mathrm{L}$. & 1 & 21.8 & 1.1 \\
\hline Autumn Seedless & $V$. vinifera $\mathrm{L}$. & 1 & 22.1 & 1.2 \\
\hline Dabouki & $V$. vinifera $\mathrm{L}$. & 2 & 19.9 & 1.4 \\
\hline Princess & $V$. vinifera $\mathrm{L}$. & 2 & 21.5 & 1.4 \\
\hline Red Roumi & $V$. vinifera $\mathrm{L}$. & 2 & 17.3 & 1.5 \\
\hline B37-41 & $V$. rufotomentosa Small., V. shuttleworthii House, $V$. vinifera L. & 2 & 24.9 & 1.5 \\
\hline \multirow[t]{2}{*}{ Seibel 8229} & V. riparia Michx, V. labrusca L., V. vinifera L., & & & \\
\hline & $\begin{array}{l}\text { V. rupestris Scheele, V. lincecumii Buckl., V. cinerea } \\
\text { Engelm. }\end{array}$ & 1 & 19.9 & 1.5 \\
\hline \multicolumn{5}{|l|}{ Slightly resistant } \\
\hline Red Globe & V. vinifera $\mathrm{L}$. & 2 & 17.3 & 1.8 \\
\hline C63-119 & V. vinifera $\mathrm{L}$. & 2 & 20.8 & 1.9 \\
\hline Golden Muscat & V. vinifera $\mathrm{L} .$, V. labrusca $\mathrm{L}$. & 1 & 21.7 & 2.4 \\
\hline Sultanina Marble & V. vinifera $\mathrm{L}$. & 3 & 20.5 & 2.4 \\
\hline Crimson Seedless & $V$. vinifera $\mathrm{L}$. & 3 & 20.1 & 2.5 \\
\hline Rhazaki de Crete & $V$. vinifera $\mathrm{L}$. & 3 & 17.3 & 2.5 \\
\hline \multicolumn{5}{|l|}{ Moderately resistant } \\
\hline Autumn Black & V. vinifera $\mathrm{L}$. & 3 & 18.0 & 3.2 \\
\hline Vanessa Seedless & V. vinifera L., V. labrusca $\mathrm{L}$. & 1 & 20.6 & 3.4 \\
\hline \multirow[t]{2}{*}{ Seyve Villard 20-365 } & V. berlandieri Planch., V. lincecumii Buckl., & & & \\
\hline & V. rupestris Scheele, V. vinifera L., V. labrusca L. & 3 & 18.1 & 3.5 \\
\hline Emperor & $V$. vinifera $\mathrm{L}$. & 4 & 16.8 & 4.5 \\
\hline N.Y. 36661 & V. vinifera L., V. labrusca $\mathrm{L}$. & 2 & 22.2 & 5.1 \\
\hline Remaily & $\begin{array}{l}\text { V. labrusca L., V. vinifera L., V. berlandieri Planch., } \\
\text { V. lincecumii Buckl., V. rupestri Scheele }\end{array}$ & 3 & 22.7 & 5.3 \\
\hline \multicolumn{5}{|l|}{ Highly resistant } \\
\hline Niagara & V. labrusca L. & 3 & 18.6 & 6.8 \\
\hline \multirow[t]{2}{*}{ Seyve Villard 12-375 } & V. berlandieri Planch., V. lincecumii Buckl., & & & \\
\hline & $V$. rupestris Scheele, $V$. vinifera L., V. labrusca L. & 2 & 19.0 & 7.5 \\
\hline Bloodworth 81-107-11 & $V$. rotundifolia Michx, $V$. vinifera & 3 & 19.7 & 7.6 \\
\hline B36-55 & V. vinifera L., V. rupestris Scheele, V. lincecumii Buckl. & 3 & 15.8 & 7.9 \\
\hline Strawberry Grape & V. labrusca L. & 2 & 26.0 & 8.2 \\
\hline Last Rose & V. lincecumii Buckl., V. labrusca L., V. vinifera $\mathrm{L}$. & 3 & 20.4 & 8.7 \\
\hline Urbana & V. labrusca L., V. vinifera $\mathrm{L}$. & 2 & 21.0 & 10.1 \\
\hline Niabell & V. labrusca L. & 2 & 16.5 & 10.6 \\
\hline Mars & V. vinifera, V. labrusca $\mathrm{L}$. & 3 & 20.7 & 12.8 \\
\hline V. Hybrid Fredonia & V. labrusca L. & 2 & 18.7 & 13.3 \\
\hline Muscat Angel & V. labrusca L. hybrid & 3 & 19.8 & 14.0 \\
\hline
\end{tabular}


fied by their retention times and UV spectra from 245 to $380 \mathrm{~nm}$. High-performance liquid chromatography (Series 1050, Hewlett Packard, Santa Clara, CA) analysis with a guard column (Phenomenex, P/NO 03A-4097-EO, type Prodigy $5 \mu$ octyldecyl silane [ODS] (3) 100Å, $30 \times 4.6 \mathrm{~mm}$ ), column (Phenomenex, P/NO 0064097-EO, type Prodigy $5 \mu$ ODS (3) $100 \AA$, $250 \times 4.6 \mathrm{~mm}$ ), and a diode array UV-visible detector was used for analysis. Chromatography was performed at $30^{\circ} \mathrm{C}$ at a flow rate of $1.0 \mathrm{ml} / \mathrm{min}$. Detection wavelength was 280 and $306 \mathrm{~nm}$. A sample volume of $25 \mu \mathrm{l}$ was passed through a membrane filter $(0.45 \mu \mathrm{m})$ before injection. A linear gradient of $2 \%$ glacial acetic acid (solvent $\mathrm{A}$ ) and $80 \%$ acetonitrile plus $0.4 \%$ glacial acetic acid (solvent B) was delivered according to the program described in Table 1.
Surface exudates. The water soluble organic carbon content of berry exudates was assessed. Three replicates of 35 whole berries, each with the pedicels attached, were shaken on a reciprocating shaker with a $10-\mathrm{cm}$ displacement at 60 cycles per min in $150 \mathrm{ml}$ of organic free water for $10 \mathrm{~min}$. The water extract was passed through a $0.45-\mu \mathrm{m}$-pore-size filter, and organic molecule content was determined with a total organic carbon kit (TOC low range, Hach, Loveland, CO). The extract was acidified to $\mathrm{pH} 2$ with sodium bisulfate buffer and stirred for $10 \mathrm{~min}$ to remove dissolved carbon dioxide. In the outside vial, organic carbon in the sample was digested by persulfate and sulfuric acid to form carbon dioxide, which diffused into the inner ampoule, which contained a $\mathrm{pH}$ indicator. The indicated $\mathrm{pH}$ was correlated with the amount of

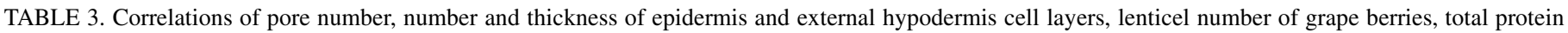

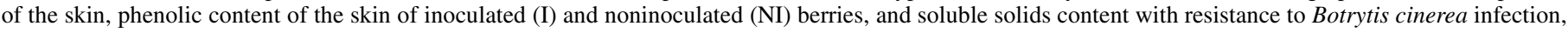
$2000^{\mathrm{a}}$

\begin{tabular}{|c|c|c|c|c|c|c|c|c|c|}
\hline & & \multirow{2}{*}{$\begin{array}{l}\text { Number } \\
\text { of pores }\end{array}$} & \multicolumn{2}{|c|}{$\begin{array}{c}\text { Epidermal and } \\
\text { hypodermal cell layers }\end{array}$} & \multirow{2}{*}{$\begin{array}{l}\text { Number of } \\
\text { lenticels }\end{array}$} & \multirow[b]{2}{*}{ Total protein } & \multicolumn{2}{|c|}{ Phenol $^{\mathrm{b}}$} & \multirow{2}{*}{$\begin{array}{l}\text { Soluble } \\
\text { Solids }\end{array}$} \\
\hline & & & Number of & Thickness of & & & $\mathrm{NI}$ & I & \\
\hline \multirow[t]{2}{*}{ Resistance factor } & $\mathrm{PC}^{\mathrm{c}}$ & -0.696 & 0.617 & 0.512 & $\ldots$ & $\ldots$ & $\ldots$ & $\ldots$ & -0.522 \\
\hline & $\mathrm{Sig}^{\mathrm{d}}$ & $<0.0001$ & 0.0008 & 0.0074 & NS & NS & NS & NS & 0.0062 \\
\hline \multirow[t]{2}{*}{ Number of pores } & $\mathrm{PC}$ & $\ldots$ & -0.428 & $\ldots$ & $\ldots$ & $\ldots$ & $\ldots$ & $\ldots$ & $\ldots$ \\
\hline & Sig & $\ldots$ & 0.0288 & NS & NS & NS & NS & NS & NS \\
\hline \multirow{2}{*}{$\begin{array}{l}\text { Number of epidermal and } \\
\text { hypodermal cell layers }\end{array}$} & $\mathrm{PC}$ & $\ldots$ & $\ldots$ & 0.757 & $\ldots$ & $\ldots$ & $\cdots$ & $\ldots$ & -0.588 \\
\hline & Sig & $\ldots$ & $\ldots$ & $<0.0001$ & NS & NS & NS & NS & 0.0016 \\
\hline \multirow{2}{*}{$\begin{array}{l}\text { Thickness of epidermal and } \\
\text { hypodermal cell layers }\end{array}$} & $\mathrm{PC}$ & $\ldots$ & $\ldots$ & $\ldots$ & $\ldots$ & $\ldots$ & $\cdots$ & $\cdots$ & -0.406 \\
\hline & Sig & $\ldots$ & $\ldots$ & $\ldots$ & NS & NS & NS & NS & 0.0039 \\
\hline \multirow[t]{2}{*}{ Number of lenticels } & $\mathrm{PC}$ & $\ldots$ & $\ldots$ & $\ldots$ & $\ldots$ & -0.411 & $\ldots$ & $\ldots$ & $\ldots$ \\
\hline & Sig & $\cdots$ & $\cdots$ & $\cdots$ & $\cdots$ & 0.0372 & NS & NS & NS \\
\hline \multirow[t]{2}{*}{ Total protein } & $\mathrm{PC}$ & $\ldots$ & $\ldots$ & $\ldots$ & $\ldots$ & $\ldots$ & $\ldots$ & $\ldots$ & $\ldots$ \\
\hline & Sig & $\ldots$ & $\ldots$ & $\ldots$ & $\ldots$ & $\ldots$ & NS & NS & NS \\
\hline \multirow[t]{2}{*}{ Phenol NI } & $\mathrm{PC}$ & $\ldots$ & $\ldots$ & $\ldots$ & $\ldots$ & $\ldots$ & $\ldots$ & -0.905 & $\ldots$ \\
\hline & Sig & $\ldots$ & $\ldots$ & $\ldots$ & $\ldots$ & $\ldots$ & $\ldots$ & $<0.0001$ & NS \\
\hline \multirow[t]{2}{*}{ Phenol I } & $\mathrm{PC}$ & $\ldots$ & $\ldots$ & $\ldots$ & $\ldots$ & $\ldots$ & $\ldots$ & $\ldots$ & $\ldots$ \\
\hline & Sig & $\ldots$ & $\ldots$ & $\ldots$ & $\ldots$ & $\ldots$ & $\ldots$ & $\ldots$ & NS \\
\hline
\end{tabular}

a NS, not significant.

b Amount of phenol detected in noninoculated (NI) and inoculated (I) grape berries.

c Pearson correlation.

d Significance 2-tailed.

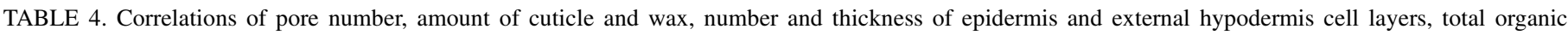
carbon (TOC), cluster density, and soluble solids content with resistance to Botrytis cinerea infection of grape berries, $2001^{\mathrm{a}}$

\begin{tabular}{|c|c|c|c|c|c|c|c|c|c|}
\hline & & \multirow{2}{*}{$\begin{array}{l}\text { Number } \\
\text { of pores }\end{array}$} & \multirow{2}{*}{$\begin{array}{l}\text { Cuticle } \\
\text { content }\end{array}$} & \multirow{2}{*}{$\begin{array}{l}\text { Wax } \\
\text { content }\end{array}$} & \multicolumn{2}{|c|}{$\begin{array}{c}\text { Epidermal and } \\
\text { hypodermal cell layers }\end{array}$} & \multirow[b]{2}{*}{ TOC } & \multirow{2}{*}{$\begin{array}{l}\text { Cluster } \\
\text { density }\end{array}$} & \multirow{2}{*}{$\begin{array}{l}\text { Soluble } \\
\text { solids }\end{array}$} \\
\hline & & & & & Number of & Thickness of & & & \\
\hline \multirow[t]{2}{*}{ Resistance factor } & $\mathrm{PC}^{\mathrm{b}}$ & -0.678 & 0.516 & 0.560 & 0.415 & 0.333 & $\ldots$ & $\ldots$ & -0.392 \\
\hline & $\mathrm{Sig}^{\mathrm{c}}$ & $<0.0001$ & 0.0008 & 0.0002 & 0.007 & 0.0332 & NS & NS & 0.0111 \\
\hline \multirow[t]{2}{*}{ Number of pores } & $\mathrm{PC}$ & $\cdots$ & -0.625 & -0.810 & -0.365 & -0.502 & $\ldots$ & 0.456 & $\cdots$ \\
\hline & Sig & $\ldots$ & $<0.0001$ & $<0.0001$ & 0.0190 & 0.0008 & NS & 0.0027 & NS \\
\hline \multirow[t]{2}{*}{ Cuticle content } & $\mathrm{PC}$ & $\cdots$ & $\cdots$ & 0.477 & $\ldots$ & $\ldots$ & $\ldots$ & -0.3739 & $\ldots$ \\
\hline & Sig & $\ldots$ & $\cdots$ & 0.0021 & NS & NS & NS & 0.0190 & NS \\
\hline \multirow[t]{2}{*}{ Wax content } & PC & $\ldots$ & $\ldots$ & $\ldots$ & 0.318 & 0.389 & $\ldots$ & $\ldots$ & $\ldots$ \\
\hline & Sig & $\ldots$ & $\ldots$ & $\ldots$ & 0.0456 & 0.0130 & NS & NS & NS \\
\hline \multirow{2}{*}{$\begin{array}{l}\text { Number of epidermal } \\
\text { and hypodermal cell layers }\end{array}$} & PC & $\ldots$ & $\ldots$ & $\ldots$ & $\ldots$ & 0.745 & $\ldots$ & $\ldots$ & $\ldots$ \\
\hline & Sig & $\ldots$ & $\ldots$ & $\ldots$ & $\ldots$ & $<0.0001$ & NS & NS & NS \\
\hline \multirow{2}{*}{$\begin{array}{l}\text { Thickness of epidermal } \\
\text { and hypodermal cell layers }\end{array}$} & PC & $\ldots$ & $\ldots$ & $\ldots$ & $\ldots$ & $\ldots$ & $\ldots$ & $\ldots$ & $\ldots$ \\
\hline & Sig & $\ldots$ & $\ldots$ & $\ldots$ & $\ldots$ & $\ldots$ & NS & NS & NS \\
\hline \multirow[t]{2}{*}{ TOC } & PC & $\ldots$ & $\ldots$ & $\ldots$ & $\ldots$ & $\ldots$ & $\ldots$ & $\ldots$ & $\ldots$ \\
\hline & Sig & $\ldots$ & $\ldots$ & $\ldots$ & $\ldots$ & $\ldots$ & $\ldots$ & NS & NS \\
\hline \multirow[t]{2}{*}{ Cluster density } & $\mathrm{PC}$ & $\ldots$ & $\ldots$ & $\ldots$ & $\ldots$ & $\ldots$ & $\ldots$ & $\ldots$ & $\ldots$ \\
\hline & Sig & $\ldots$ & $\ldots$ & $\ldots$ & $\ldots$ & $\ldots$ & $\ldots$ & $\ldots$ & NS \\
\hline
\end{tabular}

${ }^{a}$ NS, not significant.

b Pearson correlation.

c Significance 2-tailed. 
carbonic acid produced, which was itself a function of the total organic carbon present in the sample.

Statistical analysis. The conidia $\mathrm{IC}_{50}$ for all entries was estimated by linear regression. To normalize the data, appropriate transformations were determined empirically using normal probability plots, and the transformations were applied before bivariate analysis was performed. To determine if significant correlations existed between the $\mathrm{R}$ factor and morphological, anatomical, or chemical features of the berries, Pearson's correlation coefficient was calculated by bivariate analysis (CORR procedure). For multiple regression analysis, we used the REG procedure by SAS (SAS Institute, Cary, NC).

\section{RESULTS}

The concentration of conidia $\left(\mathrm{IC}_{50}\right)$ of $B$. cinerea that caused $50 \%$ of the mature (18.6 to $25 \%$ soluble solids content) berries of $\mathrm{cv}$. Thompson Seedless to become infected was consistently about $5 \times 10^{4}$ per ml. Among 102 entries (data not shown) tested over 4 years, only 11 were highly resistant. The resistance to infection by $B$. cinerea of most entries was similar in repeated tests. Resistance to infection by $B$. cinerea, genetic background, and soluble solids content at the time of harvest of each entry whose morphological, anatomical, and chemical properties were evaluated are shown in Table 2. Entries are grouped in categories of similar resistance factors: (i) 0 to 1.5 , highly susceptible; (ii) 1.6 to 2.5 , slightly resistant; (iii) 3.0 to 5.5, moderately resistant; and (iv) $>5.5$, highly resistant. Little or no resistance to gray mold existed in the most popular $V$. vinifera cultivars. Moderate resistance within $V$. vinifera was identified in 'Emperor' and 'Autumn Black'. Highly resistant grapes included 'Niagara', 'Seyve Villard 12-375', 'Bloodworth 81-107-11', B36-55, 'Strawberry Grape', 'Last Rose', 'Urbana', 'Niabell', 'Mars', 'Fredonia', and 'Muscat
Angel'. Highly resistant grapes were not pure $V$. vinifera; all were V. labrusca, V. labrusca $\times$ V. vinifera, or other complex hybrids.

Mean soluble solids contents were 21.5, 19.6, 19.7, and 19.7\% for highly susceptible, slightly resistant, moderately resistant, and highly resistant entries, respectively (Table 2). Soluble solids content was negatively correlated with the resistance to gray mold and the thickness and number of cell layers in the epidermis and external hypodermis (Tables 3 and 4).

The number of pores and lenticels and the number and thickness of epidermal and external hypodermal cell layers of 26 cultivars and selections were assessed in 2000 (Table 5). In 2001, the number of pores, the number and thickness of epidermal and external hypodermal cell layers, cluster density, and cuticle and wax content of 41 entries were assessed (Table 6).

The mean numbers of pores per $50 \mathrm{~mm}^{2}$ of berry surface of entries highly susceptible and highly resistant to $B$. cinerea infection were 21.0 and 0.7 , respectively, in 2000 (Table 5), and 24.3 and 1.6, respectively, in 2001 (Table 6).

The mean numbers of cell layers in epidermis and external hypodermis of entries highly susceptible and highly resistant to $B$. cinerea infection were 4.1 and 5.6, respectively, in 2000 (Table 5), and 4.1 and 5.1, respectively, in 2001 (Table 6).

The mean thickness of epidermis and external hypodermis cell layers of entries highly susceptible and highly resistant to $B$. cinerea infection was 40.1 and $56.0 \mu \mathrm{m}$, respectively, in 2000 (Table 5), and 48.2 and $61.5 \mu \mathrm{m}$, respectively, in 2001 (Table 6).

In both years, the number of pores was negatively correlated with the resistance of berries to $B$. cinerea infection, whereas the number and thickness of cell layers in epidermis and external hypodermis were positively correlated with the resistance to infection (Tables 3 and 4).

The mean number of lenticels was 2.2 in all cultivars, except 'Bloodworth 81-107-11', which had 26 lenticels per $50 \mathrm{~mm}^{2}$ of

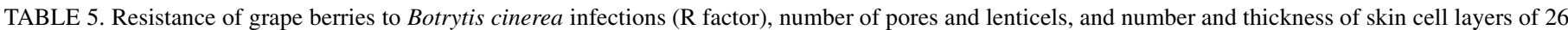
cultivars and selections, Fresno County, California, 2000

\begin{tabular}{|c|c|c|c|c|c|}
\hline Cultivar & $\mathrm{R}$ factor & Pores $^{\mathrm{a}}$ & Lenticels $^{\mathrm{b}}$ & Cell layers in the $\operatorname{skin}^{\mathrm{c}}$ & Thickness of skin cell layers $(\mu \mathrm{m})^{\mathrm{d}}$ \\
\hline \multicolumn{6}{|l|}{ Highly susceptible } \\
\hline Baroque 11-8-58 & 0.1 & $8.1 \pm 4.8$ & $2.4 \pm 0.5$ & $5.0 \pm 1.1$ & $55.7 \pm 9.6$ \\
\hline C94-71 & 0.1 & $29.8 \pm 12.8$ & $2.0 \pm 0.1$ & $3.5 \pm 0.5$ & $25.2 \pm 6.7$ \\
\hline B1479-1 & 0.2 & $3.7 \pm 0.9$ & $1.9 \pm 0.5$ & $3.8 \pm 0.4$ & $42.0 \pm 6.3$ \\
\hline C89-44 & 0.4 & $34.1 \pm 16.3$ & $2.9 \pm 0.5$ & $3.8 \pm 1.0$ & $39.3 \pm 13.1$ \\
\hline Ruby Seedless & 0.8 & $53.1 \pm 15.2$ & $2.2 \pm 0.3$ & $5.0 \pm 0.9$ & $47.2 \pm 10.5$ \\
\hline C77-107 & 0.9 & $25.9 \pm 7.3$ & $1.3 \pm 0.2$ & $3.2 \pm 0.8$ & $32.7 \pm 4.9$ \\
\hline Thompson Seedless & 1.0 & $19.3 \pm 4.0$ & $3.5 \pm 0.6$ & $4.8 \pm 0.8$ & $47.5 \pm 7.1$ \\
\hline B34-82 & 1.1 & $21.9 \pm 9.3$ & $1.8 \pm 0.2$ & $3.7 \pm 0.8$ & $48.8 \pm 12.6$ \\
\hline Princess & 1.4 & $17.0 \pm 8.5$ & $3.4 \pm 0.3$ & $4.5 \pm 1.4$ & $40.7 \pm 19.2$ \\
\hline B37-41 & 1.5 & $4.7 \pm 4.4$ & $1.2 \pm 0.2$ & $3.5 \pm 0.5$ & $24.0 \pm 4.3$ \\
\hline Seibel 8229 & 1.5 & $14.1 \pm 5.3$ & $6.3 \pm 0.4$ & $4.3 \pm 0.8$ & $38.5 \pm 11.4$ \\
\hline \multicolumn{6}{|l|}{ Slightly resistant } \\
\hline Golden Muscat & 2.4 & $0.8 \pm 0.4$ & $1.4 \pm 0.3$ & $5.5 \pm 1.0$ & $41.8 \pm 7.4$ \\
\hline Rhazaki de Crete & 2.5 & $13.6 \pm 8.4$ & $2.9 \pm 0.4$ & $5.2 \pm 0.8$ & $58.0 \pm 11.2$ \\
\hline \multicolumn{6}{|l|}{ Moderately resistant } \\
\hline Autumn Black & 3.2 & $15.7 \pm 3.9$ & $0.7 \pm 0.3$ & $5.3 \pm 1.0$ & $56.8 \pm 17.3$ \\
\hline Seyve Villard 20-365 & 3.5 & $9.3 \pm 2.8$ & $2.5 \pm 0.8$ & $4.2 \pm 0.4$ & $41.5 \pm 12.5$ \\
\hline Emperor & 4.5 & $12.5 \pm 2.6$ & $2.3 \pm 0.1$ & $6.8 \pm 0.8$ & $69.6 \pm 24.1$ \\
\hline Remaily & 5.3 & $1.4 \pm 0.8$ & $3.2 \pm 0.8$ & $5.8 \pm 1.2$ & $62.8 \pm 14.0$ \\
\hline \multicolumn{6}{|l|}{ Highly resistant } \\
\hline Niagara & 6.8 & $1.6 \pm 1.2$ & $3.5 \pm 0.6$ & $5.8 \pm 1.0$ & $63.7 \pm 24.0$ \\
\hline Bloodworth 81-107-11 & 7.6 & $0.8 \pm 0.7$ & $26.1 \pm 1.5$ & $5.4 \pm 0.5$ & $49.6 \pm 10.6$ \\
\hline B36-55 & 7.9 & $1.4 \pm 5.1$ & $3.2 \pm 0.5$ & $4.2 \pm 0.8$ & $60.8 \pm 16.0$ \\
\hline Strawberry Grape & 8.2 & $0.1 \pm 0.1$ & $2.8 \pm 0.8$ & $6.0 \pm 0.6$ & $46.3 \pm 7.7$ \\
\hline Urbana & 10.1 & $1.0 \pm 0.6$ & $1.1 \pm 0.4$ & $5.3 \pm 1.2$ & $64.2 \pm 20.3$ \\
\hline Niabell & 10.6 & $0.4 \pm 0.5$ & $0.9 \pm 0.3$ & $7.0 \pm 0.7$ & $60.8 \pm 10.3$ \\
\hline Mars & 12.8 & $0.6 \pm 0.6$ & $1.1 \pm 0.3$ & $5.7 \pm 0.5$ & $52.8 \pm 7.8$ \\
\hline Fredonia & 13.3 & $0.0 \pm 0.0$ & $1.2 \pm 0.5$ & $5.2 \pm 1.0$ & $46.3 \pm 6.6$ \\
\hline Muscat Angel & 14.0 & $0.2 \pm 0.3$ & $1.5 \pm 0.4$ & $6.0 \pm 0.9$ & $59.8 \pm 10.0$ \\
\hline
\end{tabular}

${ }^{a}$ Mean number of pores per $50 \mathrm{~mm}^{2}$ of skin surface \pm standard deviation, $n=40$.

b Mean number of lenticels per $50 \mathrm{~mm}^{2}$ of skin surface \pm standard deviation, $n=40$.

c Mean number of epidermis and external hypodermis cell layers \pm standard deviation, $n=12$.

${ }^{\mathrm{d}}$ Mean thickness (micrometers) of epidermis and external hypodermis cell layers \pm standard deviation, $n=12$. 
berry surface (Table 5). Number of lenticels was not correlated with gray mold resistance (Table 3 ).

The mean cuticle content was $4.2 \mu \mathrm{g}$ per $\mathrm{mm}^{2}$ of berry skin among sensitive cultivars and $8.9 \mu \mathrm{g}$ per $\mathrm{mm}^{2}$ of berry skin among resistant cultivars. Wax content was $1.1 \mu \mathrm{g}$ per $\mathrm{mm}^{2}$ of berry skin among sensitive entries and $2.6 \mu \mathrm{g}$ per $\mathrm{mm}^{2}$ of berry skin among resistant entries (Table 6). Resistance of berries to $B$. cinerea was positively correlated with the cuticle and wax contents (Table 4).

Anatomical features were significantly correlated among themselves. The number of epidermal and external hypodermal cell layers was significantly positively correlated with their width. The number of epidermal and external hypodermal cell layers was negatively correlated with the number of pores and positively correlated with the amount of wax (Tables 3 and 4). Cluster density was not correlated with resistance, but was positively correlated with the number of pores and negatively correlated with cuticle content. Accordingly, the number of pores was negatively corre- lated with the cuticle and wax content and number and thickness of epidermal and hypodermal cell layers (Table 4).

Total protein content of berry skins was 2.1 to $8.6 \mathrm{mg} / \mathrm{g}$ fresh weight (Table 7). Before induction, total phenolics content was 0.63 to $7.18 \mathrm{mg} / \mathrm{g}$, whereas after induction, the content was 0.55 to $8.19 \mathrm{mg} / \mathrm{g}$ (Table 7). Among sensitive entries, the mean total phenolic content before induction was $2.1 \mathrm{mg} / \mathrm{g}$, and $2.5 \mathrm{mg} / \mathrm{g}$ after induction. Among highly resistant entries, the mean total phenolic content before induction was $2.1 \mathrm{mg} / \mathrm{g}$, and $2.2 \mathrm{mg} / \mathrm{g}$ after induction. Before induction, catechin was detected in one selection, B34-82, of 26 examined, and it contained $139.37 \mu \mathrm{g} / \mathrm{g}$ (Table 7). After induction, 10.86 to $167.35 \mu \mathrm{g}$ of catechin per g was detected in 5 of 26 entries. The highest catechin content was in B34-82, which was very susceptible to infection by $B$. cinerea. Before induction, trans-resveratrol was detected in 'Rhazaki de Crete' and B3655 and was 5.43 and $9.47 \mu \mathrm{g} / \mathrm{g}$ fresh weight, respectively (Table 7). trans-Resveratrol content (detected in 13 entries) after induction was 0.43 to $113.12 \mu \mathrm{g} / \mathrm{g}$. Before induction, cis-resveratrol was

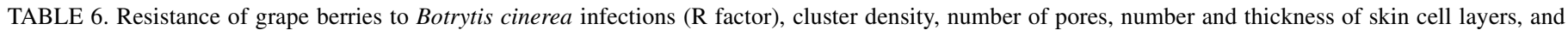
cuticle and wax content on the berry skin of 41 cultivars and selections, Fresno County, California, 2001

\begin{tabular}{|c|c|c|c|c|c|c|c|}
\hline Cultivar & $\mathrm{R}$ factor & $\begin{array}{l}\text { Cluster } \\
\text { density }^{\mathrm{a}}\end{array}$ & Pores $^{b}$ & $\begin{array}{l}\text { Cell layers } \\
\text { in the skin }{ }^{c}\end{array}$ & $\begin{array}{c}\text { Thickness of } \\
\text { skin cell layers }(\mu \mathrm{m})^{\mathrm{d}}\end{array}$ & Cuticle content $\mathrm{e}^{\mathrm{e}}$ & Wax content $\mathrm{f}^{\mathrm{f}}$ \\
\hline \multicolumn{8}{|l|}{ Highly susceptible } \\
\hline Baroque 11-8-58 & 0.1 & 7 & $10.9 \pm 4.4$ & $4.2 \pm 0.8$ & $43.4 \pm 11.9$ & $4.19 \pm 0.7$ & $1.80 \pm 0.1$ \\
\hline Flame Seedless & 0.1 & 5 & $20.1 \pm 7.1$ & $3.8 \pm 1.5$ & $53.2 \pm 42.2$ & Missing & $1.21 \pm 0.1$ \\
\hline C94-71 & 0.1 & 5 & $39.4 \pm 15.7$ & $3.2 \pm 1.0$ & $32.0 \pm 15.0$ & $3.34 \pm 0.3$ & $0.67 \pm 0.1$ \\
\hline A61-16 & 0.2 & 5 & $45.2 \pm 12.7$ & $4.0 \pm 0.9$ & $48.7 \pm 11.2$ & $1.86 \pm 0.1$ & $1.04 \pm 0.1$ \\
\hline B1479-1 & 0.2 & 4 & $2.8 \pm 1.6$ & $3.7 \pm 0.5$ & $61.2 \pm 22.2$ & $5.58 \pm 0.9$ & $1.65 \pm 0.3$ \\
\hline C89-44 & 0.4 & 3 & $10.2 \pm 5.8$ & $3.8 \pm 1.0$ & $36.7 \pm 12.6$ & $3.64 \pm 0.6$ & $1.29 \pm 0.2$ \\
\hline Autumn Royal & 0.7 & 5 & $8.2 \pm 3.1$ & $5.0 \pm 0.9$ & $65.8 \pm 17.4$ & $6.69 \pm 1.4$ & $0.78 \pm 0.2$ \\
\hline Ruby Seedless & 0.8 & 5 & $75.2 \pm 17.8$ & $5.7 \pm 1.8$ & $52.5 \pm 15.2$ & $5.12 \pm 0.5$ & $0.78 \pm 0.1$ \\
\hline Thompson Seedless & 1.0 & 6 & $34.3 \pm 16.5$ & $3.8 \pm 0.8$ & $41.0 \pm 21.7$ & $3.60 \pm 0.1$ & $0.41 \pm 0.1$ \\
\hline Queen & 1.0 & 5 & $8.3 \pm 4.9$ & $6.2 \pm 1.3$ & $59.2 \pm 16.6$ & $5.59 \pm 0.8$ & $1.88 \pm 0.0$ \\
\hline B34-82 & 1.1 & 5 & $22.0 \pm 8.4$ & $4.0 \pm 0.6$ & $49.7 \pm 17.9$ & $4.08 \pm 0.2$ & $1.09 \pm 0.1$ \\
\hline A59-91 & 1.1 & 5 & $51.7 \pm 24.5$ & $3.3 \pm 1.0$ & $41.5 \pm 13.9$ & $4.03 \pm 1.4$ & $1.15 \pm 0.0$ \\
\hline Autumn Seedless & 1.2 & 5 & $8.0 \pm 6.0$ & $4.3 \pm 1.4$ & $46.7 \pm 14.4$ & $3.57 \pm 0.5$ & $1.20 \pm 0.2$ \\
\hline Dabouki & 1.3 & 6 & $18.9 \pm 6.7$ & $2.7 \pm 0.5$ & $39.2 \pm 25.1$ & $2.68 \pm 0.2$ & $0.68 \pm 0.1$ \\
\hline Princess & 1.4 & 4 & $12.2 \pm 9.5$ & $4.7 \pm 1.2$ & $50.3 \pm 17.9$ & $2.77 \pm 0.7$ & $0.66 \pm 0.1$ \\
\hline Red Roumi & 1.5 & 5 & $18.5 \pm 6.4$ & $4.3 \pm 1.0$ & $50.2 \pm 21.7$ & $5.50 \pm 0.9$ & $0.66 \pm 0.1$ \\
\hline B37-41 & 1.5 & 5 & $4.7 \pm 4.4$ & $3.7 \pm 0.8$ & $56.7 \pm 36.9$ & $4.19 \pm 0.4$ & $1.80 \pm 0.1$ \\
\hline Seibel 8229 & 1.5 & 5 & $47.9 \pm 16.0$ & $3.8 \pm 0.8$ & $40.0 \pm 13.6$ & $4.14 \pm 0.4$ & $1.47 \pm 0.2$ \\
\hline \multicolumn{8}{|l|}{ Slightly resistant } \\
\hline Red Globe & 1.8 & 5 & $6.5 \pm 2.4$ & $4.7 \pm 1.0$ & $52.7 \pm 26.3$ & $3.03 \pm 0.6$ & $0.98 \pm 0.1$ \\
\hline C63-119 & 1.9 & 7 & $30.7 \pm 14.4$ & $6.0 \pm 1.4$ & $60.0 \pm 17.5$ & $2.45 \pm 0.3$ & $0.96 \pm 0.1$ \\
\hline Golden Muscat & 2.4 & 6 & $1.4 \pm 1.1$ & $6.2 \pm 1.0$ & $70.5 \pm 29.5$ & $6.16 \pm 0.7$ & $2.14 \pm 0.1$ \\
\hline Sultanina Marble & 2.4 & 8 & $42.7 \pm 15.4$ & $3.3 \pm 0.5$ & $24.2 \pm 5.0$ & $3.60 \pm 0.7$ & $1.20 \pm 0.1$ \\
\hline Crimson Seedless & 2.5 & 5 & $14.2 \pm 7.7$ & $5.0 \pm 0.6$ & $48.0 \pm 15.3$ & $8.85 \pm 0.9$ & $1.08 \pm 0.2$ \\
\hline Rhazaki de Crete & 2.5 & 6 & $15.1 \pm 7.1$ & $5.2 \pm 1.3$ & $47.2 \pm 7.4$ & $2.27 \pm 0.2$ & $0.86 \pm 0.1$ \\
\hline \multicolumn{8}{|l|}{ Moderately resistant } \\
\hline Autumn Black & 3.2 & 5 & $10.3 \pm 4.0$ & $4.8 \pm 1.0$ & $53.3 \pm 11.7$ & $5.31 \pm 0.4$ & $1.24 \pm 0.0$ \\
\hline Vanessa Seedless & 3.4 & 4 & $1.2 \pm 1.0$ & $4.4 \pm 0.5$ & $47.6 \pm 11.5$ & $\ldots$ & $\ldots$ \\
\hline Seyve Villard 20-365 & 3.5 & 6 & $9.6 \pm 4.3$ & $4.4 \pm 0.5$ & $63.8 \pm 26.5$ & $4.66 \pm 0.3$ & $1.54 \pm 0.0$ \\
\hline Emperor & 4.5 & 5 & $6.3 \pm 2.0$ & $5.0 \pm 2.1$ & $71.0 \pm 20.9$ & $13.84 \pm 2.9$ & $1.02 \pm 0.2$ \\
\hline N.Y. 36661 & 5.1 & 4 & $1.2 \pm 0.6$ & $3.5 \pm 0.5$ & $46.8 \pm 13.4$ & $5.93 \pm 0.1$ & $1.81 \pm 0.1$ \\
\hline Remaily & 5.3 & 5 & $0.7 \pm 0.5$ & $4.5 \pm 1.0$ & $34.8 \pm 15.3$ & $25.59 \pm 2.5$ & $1.87 \pm 0.1$ \\
\hline \multicolumn{8}{|l|}{ Highly resistant } \\
\hline Niagara & 6.8 & 5 & $0.3 \pm 0.4$ & $6.7 \pm 1.2$ & $98.5 \pm 41.7$ & $8.50 \pm 0.5$ & $2.44 \pm 0.2$ \\
\hline Seyve Villard 12-375 & 7.5 & 5 & $2.7 \pm 2.4$ & $4.0 \pm 0.9$ & $38.7 \pm 8.9$ & $5.67 \pm 1.0$ & $2.17 \pm 0.1$ \\
\hline Bloodworth 81-107-11 & 7.6 & 3 & $0.4 \pm 0.5$ & $4.0 \pm 0.6$ & $46.2 \pm 22.3$ & $26.03 \pm 5.1$ & $1.78 \pm 0.1$ \\
\hline B36-55 & 7.9 & 5 & $11.3 \pm 4.6$ & $5.8 \pm 0.5$ & $54.8 \pm 7.4$ & $7.01 \pm 0.7$ & $1.42 \pm 0.1$ \\
\hline Strawberry & 8.2 & 4 & $0.6 \pm 0.5$ & $4.7 \pm 1.4$ & $49.3 \pm 15.0$ & $6.17 \pm 0.6$ & $2.39 \pm 0.1$ \\
\hline Last Rose & 8.7 & 6 & $1.2 \pm 0.7$ & $4.8 \pm 1.1$ & $60.6 \pm 12.6$ & $6.68 \pm 0.4$ & $2.93 \pm 0.2$ \\
\hline Urbana & 10.1 & 5 & $0.3 \pm 0.4$ & $4.3 \pm 0.5$ & $43.2 \pm 8.8$ & $7.71 \pm 0.2$ & $2.84 \pm 0.2$ \\
\hline Niabell & 10.6 & 4 & $0.0 \pm 0.1$ & $6.0 \pm 1.3$ & $87.7 \pm 29.8$ & $9.56 \pm 1.5$ & $2.79 \pm 0.4$ \\
\hline Mars & 12.8 & 4 & $0.6 \pm 0.7$ & $5.0 \pm 0.7$ & $59.0 \pm 14.4$ & $5.47 \pm 0.9$ & $2.72 \pm 0.1$ \\
\hline Fredonia & 13.3 & 3 & $0.1 \pm 0.1$ & $5.0 \pm 1.1$ & $63.7 \pm 28.2$ & $10.16 \pm 0.4$ & $4.89 \pm 0.6$ \\
\hline Muscat Angel & 14.0 & 5 & $0.4 \pm 0.6$ & $6.0 \pm 0.9$ & $74.5 \pm 16.9$ & $4.45 \pm 0.2$ & $2.52 \pm 0.1$ \\
\hline
\end{tabular}

a Cluster density assessed on a visual scale of 1 to 9 ; where $1=$ very loose and $9=$ very tight.

b Number of pores per $50 \mathrm{~mm}^{2}$ of skin surface \pm standard deviation, $n=40$.

${ }^{c}$ Mean number of epidermis and external hypodermis cell layers \pm standard deviation, $n=12$.

d Mean thickness (micrometers) of epidermis and external hypodermis cell layers \pm standard deviation, $n=12$.

e Mean amount of cuticle, microgram per square millimeter of berry skin, $n=50$.

${ }^{\mathrm{f}}$ Mean amount of wax, microgram per square millimeter of berry skin, $n=50$. 
detected once and the content in B36-55 was $4.13 \mu \mathrm{g} / \mathrm{g}$ (Table 7). After induction, the cis-resveratrol content of three entries in which it was detected ranged from 1.86 to $8.92 \mu \mathrm{g} / \mathrm{g}$. Catechin and trans- and cis-resveratrol contents were not included in bivariate analysis, because very few entries yielded detectable quantities of these, so their inclusion would not support statistical analysis.

Bivariate analysis indicated that total protein and phenolics content of the berry skin were not significantly associated with resistance to gray mold (Table 3).

Berry water soluble surface exudates ranged from $17.0 \mu \mathrm{g} / \mathrm{cm}^{2}$ of surface of 'Seyve Villard 12-375' berries to $365.9 \mu \mathrm{g} / \mathrm{cm}^{2}$ of surface of 'Golden Muscat' berries (Table 8). Total organic carbon in aqueous berry extracts was not associated with resistance to $B$. cinerea infections (Table 3 ).

In both years, the berries of highly resistant entries consistently had few or no pores (Fig. 1). Regression analysis showed a significant relationship between a reduced number of pores and increasing resistance to $B$. cinerea infection in $2000\left(R^{2}=0.485\right)$ and $2001\left(R^{2}=0.458\right)$ (Fig. 2). The relationship between the number of pores and resistance was the predominant explanatory variable in estimating the resistance factor, although a significant increase in resistance predictability was possible by adding a second explanatory variable. Multiple regression models that incorporated all the significantly correlated features (porosity, soluble solids, amount of cuticle and wax, and number and thickness of epidermal and external hypodermal cell layers) for 2000 and 2001 data were calculated. In 2000, inclusion of soluble solids contents in the model significantly improved the $R^{2}$ value, the coefficient of determination, from 0.485 , using the resistance factor and porosity alone, to 0.716 . The model was as follows: resistance factor $=7.00-0.57$ porosity -0.26 soluble solids. Inclusion of other factors did not improve the coefficient of determination significantly. In 2001, inclusion of soluble solids contents in the model significantly improved the coefficient of determination from 0.397 , using the resistance factor and porosity alone, to 0.640 . The model was as follows: resistance factor $=6.15-0.53$ porosity -0.22 soluble solids. Inclusion of other factors did not improve the coefficient of determination significantly.

\section{DISCUSSION}

Resistance to gray mold was infrequent among the berries of the 102 cultivars and selections tested; only 11 were highly resistant to $B$. cinerea infection. Little or no resistance existed in commercial $V$. vinifera cultivars, with the exception of moderate resistance in 'Emperor' and 'Autumn Black'. Highly resistant grapes were not solely $V$. vinifera; all were V. labrusca, V. labrusca $\times V$. vinifera hybrids, or other complex hybrids.

Evidence for many defense mechanisms to $B$. cinerea infection have been described or demonstrated $(23,35)$. Prusky and Keen (42) described the obstacles that fungal pathogens must overcome before they are able to initiate disease in plants. First, the pathogen must locate and adhere to susceptible tissue and then initiate infection. The first barriers encountered are generally the cuticle and cell wall. Contact with underlying plant tissues presents the invading pathogen with a different set of barriers, most notably preformed antibiotic compounds or morphologic barriers and phytoalexins induced by the plant.

Pores in the berry surface comprise vulnerable sites for infection to happen. In our work, we found that the number of pores in

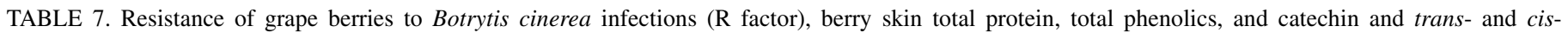
resveratrol contents before and after inoculation with B. cinerea, 2000

\begin{tabular}{|c|c|c|c|c|c|c|c|c|c|c|}
\hline \multirow[b]{2}{*}{ Cultivar } & \multirow[b]{2}{*}{$\mathrm{R}$ factor } & \multirow{2}{*}{$\begin{array}{c}\text { Total } \\
\text { protein }^{\mathrm{a}}\end{array}$} & \multicolumn{2}{|c|}{ Total phenolics ${ }^{b}$} & \multicolumn{2}{|c|}{ Catechin $^{c}$} & \multicolumn{2}{|c|}{ trans-Resveratrol $^{\mathrm{d}}$} & \multicolumn{2}{|c|}{ cis-Resveratrol $^{\mathrm{e}}$} \\
\hline & & & Initial & Induced & Initial & Induced & Initial & Induced & Initial & Induced \\
\hline \multicolumn{11}{|l|}{ Highly susceptible } \\
\hline Baroque 11-8-58 & 0.1 & $5.3 \pm 0.9$ & $0.85 \pm 0.10$ & $0.69 \pm 0.06$ & $\ldots{ }^{f}$ & $\ldots$ & $\ldots$ & $1.3 \pm 1.2$ & $\ldots$ & $\ldots$ \\
\hline C94-71 & 0.1 & $7.5 \pm 1.1$ & $3.34 \pm 0.38$ & $3.26 \pm 0.69$ & $\ldots$ & $48.6 \pm 36.9$ & $\ldots$ & $8.4 \pm 1.4$ & $\ldots$ & $\ldots$ \\
\hline B1479-1 & 0.2 & $5.0 \pm 0.4$ & $4.29 \pm 0.26$ & $3.21 \pm 0.16$ & $\ldots$ & $\ldots$ & $\ldots$ & $\ldots$ & $\ldots$ & $\ldots$ \\
\hline C89-44 & 0.4 & $4.6 \pm 0.4$ & $1.66 \pm 0.11$ & $2.45 \pm 0.12$ & $\ldots$ & $59.7 \pm 14.9$ & $\ldots$ & $\ldots$ & $\ldots$ & $\ldots$ \\
\hline Ruby Seedless & 0.8 & $3.4 \pm 0.3$ & $1.46 \pm 0.12$ & $2.39 \pm 0.31$ & $\ldots$ & $\ldots$ & $\ldots$ & $1.0 \pm 0.8$ & $\ldots$ & $\ldots$ \\
\hline B34-82 & 0.9 & $7.3 \pm 3.1$ & $6.21 \pm 0.63$ & $7.76 \pm 1.59$ & $139.0 \pm 52.1$ & $167.4 \pm 21.2$ & $\ldots$ & $11.0 \pm 1.1$ & $\ldots$ & $\ldots$ \\
\hline C77-107 & 1.0 & $6.5 \pm 1.7$ & $1.47 \pm 0.05$ & $3.68 \pm 0.39$ & $\ldots$ & $\ldots$ & $\ldots$ & $3.5 \pm 1.8$ & $\ldots$ & $\ldots$ \\
\hline Thompson Seedless & 1.1 & $4.2 \pm 1.3$ & $1.51 \pm 0.27$ & $1.23 \pm 0.06$ & $\ldots$ & $\ldots$ & $\ldots$ & $\ldots$ & $\ldots$ & $\ldots$ \\
\hline Princess & 1.4 & $2.1 \pm 0.8$ & $0.82 \pm 0.15$ & $1.30 \pm 0.02$ & $\ldots$ & $\ldots$ & $\ldots$ & $\ldots$ & $\ldots$ & $\ldots$ \\
\hline B37-41 & 1.5 & $5.3 \pm 1.3$ & $0.63 \pm 0.05$ & $0.55 \pm 0.55$ & $\ldots$ & $\ldots$ & $\ldots$ & $1.3 \pm 0.2$ & $\ldots$ & $5.1 \pm 4.8$ \\
\hline Seibel 8229 & 1.5 & $5.3 \pm 1.3$ & $0.71 \pm 0.13$ & $0.64 \pm 0.64$ & $\ldots$ & $\ldots$ & $\ldots$ & $\ldots$ & $\ldots$ & $\ldots$ \\
\hline \multicolumn{11}{|l|}{ Slightly resistant } \\
\hline Golden Muscat & 2.4 & $5.5 \pm 0.9$ & $0.80 \pm 0.12$ & $0.64 \pm 0.05$ & $\ldots$ & $\ldots$ & $\ldots$ & $0.4 \pm 0.3$ & $\ldots$ & $\ldots$ \\
\hline Rhazaki de Crete & 2.5 & $4.7 \pm 0.3$ & $0.80 \pm 0.03$ & $0.78 \pm 0.04$ & $\ldots$ & $\ldots$ & $5.4 \pm 2.0$ & $9.6 \pm 1.4$ & $\ldots$ & $1.9 \pm 1.6$ \\
\hline \multicolumn{11}{|l|}{ Moderately resistant } \\
\hline Autumn Black & 3.2 & $5.6 \pm 1.1$ & $7.18 \pm 0.48$ & $8.19 \pm 0.71$ & $\ldots$ & $97.9 \pm 30.8$ & $\ldots$ & $23.9 \pm 4.3$ & $\ldots$ & $\ldots$ \\
\hline Seyve Villard 20-365 & 3.5 & $5.5 \pm 1.0$ & $1.39 \pm 0.18$ & $1.52 \pm 0.17$ & $\ldots$ & $\ldots$ & $\ldots$ & $1.0 \pm 0.9$ & $\ldots$ & $\ldots$ \\
\hline Emperor & 4.5 & $4.4 \pm 0.6$ & $2.64 \pm 0.29$ & $3.81 \pm 0.46$ & $\ldots$ & $\ldots$ & $\ldots$ & $6.0 \pm 0.2$ & $\ldots$ & $\ldots$ \\
\hline Remaily & 5.3 & $3.9 \pm 0.1$ & $6.04 \pm 0.60$ & $2.73 \pm 0.49$ & $\ldots$ & $\ldots$ & $\ldots$ & $0.4 \pm 0.3$ & $\ldots$ & $\ldots$ \\
\hline \multicolumn{11}{|l|}{ Highly resistant } \\
\hline Niagara & 6.8 & $4.5 \pm 0.2$ & $0.91 \pm 0.08$ & $0.83 \pm 0.08$ & $\ldots$ & $\ldots$ & $\ldots$ & $\ldots$ & $\ldots$ & $\ldots$ \\
\hline Bloodworth 81-107-11 & 7.6 & $3.7 \pm 1.0$ & $2.45 \pm 0.40$ & $3.97 \pm 0.41$ & $\ldots$ & $\ldots$ & $\ldots$ & $\ldots$ & $\ldots$ & $\ldots$ \\
\hline B36-55 & 7.9 & $3.4 \pm 0.2$ & $1.55 \pm 0.17$ & $1.95 \pm 0.18$ & $\ldots$ & $\ldots$ & $9.5 \pm 0.2$ & $113.0 \pm 11.8$ & $4.1 \pm 4.0$ & $8.9 \pm 1.6$ \\
\hline Strawberry Grape & 8.2 & $7.6 \pm 0.8$ & $1.28 \pm 0.19$ & $1.18 \pm 0.11$ & $\ldots$ & $\ldots$ & $\ldots$ & $\ldots$ & $\ldots$ & $\ldots$ \\
\hline Urbana & 10.1 & $3.3 \pm 0.5$ & $1.47 \pm 0.19$ & $1.15 \pm 0.08$ & $\ldots$ & $\ldots$ & $\ldots$ & $\ldots$ & $\ldots$ & $\ldots$ \\
\hline Niabell & 10.6 & $5.4 \pm 0.7$ & $2.99 \pm 0.47$ & $2.36 \pm 0.21$ & $\ldots$ & $\ldots$ & $\ldots$ & $\ldots$ & $\ldots$ & $\ldots$ \\
\hline Mars & 12.8 & $7.0 \pm 1.5$ & $2.37 \pm 0.03$ & $2.25 \pm 0.07$ & $\ldots$ & $\ldots$ & $\ldots$ & $\ldots$ & $\ldots$ & $\ldots$ \\
\hline Fredonia & 13.3 & $8.6 \pm 3.0$ & $3.56 \pm 0.36$ & $3.28 \pm 0.07$ & $\ldots$ & $\ldots$ & $\ldots$ & $\ldots$ & $\ldots$ & $\ldots$ \\
\hline Muscat Angel & 14.0 & $6.6 \pm 0.9$ & $1.99 \pm 0.15$ & $2.66 \pm 0.47$ & $\ldots$ & $\ldots$ & $\ldots$ & $\ldots$ & $\ldots$ & $\ldots$ \\
\hline
\end{tabular}

a Amount of protein in grape berry skin \pm standard deviation, $n=3$, expressed in milligrams per gram of frozen berry skin.

$\mathrm{b}$ Amount of phenolics in grape berry skin \pm standard deviation, $n=3$, expressed in milligrams per gram of frozen berry skin.

c Amount of catechin in grape berry skin \pm standard deviation, $n=3$, expressed in micrograms per gram of frozen berry skin.

d Amount of trans-resveratrol in grape berry skin \pm standard deviation, $n=3$, expressed in micrograms per gram of frozen berry skin.

e Amount of cis-resveratrol in grape berry skin \pm standard deviation, $n=3$, expressed in micrograms per gram of frozen berry skin.

f ... Indicates below detection limit. 
the berry skin was highly correlated with susceptibility to $B$. cinerea infection. High surface porosity immediately diminishes the impact of mechanical obstacles such as wax and cuticle or the number and thickness of the skin cell layers, because the pathogen is able to bypass these barriers. Blaich et al. (5) and Eibach (15) suggested that resistance of grape berries to $B$. cinerea infection was related to the number of natural pores on the berry surface. Our results corroborate theirs and confirm that resistance to infection increases with decreasing surface porosity. Børve et al. (6) reported a significant correlation between cuticular fractures on the surface of sweet cherries and an increased number of $B$. cinerea infections. Insects can play an important role by wounding the berries and depositing conidia or mycelia in the wound cavity, which is an important prerequisite for symptom development. Fruit flies feed mainly around wounds on the berry, where they place conidia and mycelial fragments; these inoculated wounds later develop disease symptoms (9,22).

Resistance to $B$. cinerea increased with an increase in the amount of wax on the surface of the berries. These results corroborate those of Percival et al. (38) and Marois et al. (33). More wax increases water repellency, thus reducing the pathogen adhesion to the cuticle $(15,21)$. We found cuticle content to be positively correlated with resistance to $B$. cinerea infection. The cuticle is the first barrier to penetration in the infection process, and it is considered primarily a physical barrier $(20,45)$. American species with a cuticle thickness from $4 \mu \mathrm{m}$ (V. rupestris) to $10 \mu \mathrm{m}$ (V. coriacea) have more resistant berries than European species ( $V$. vinifera) in which the cuticle is 1.5 to $3.8 \mu \mathrm{m}$ thick (45). Within $V$.

TABLE 8. Total organic compound content (TOC) of water extracts of grape berry surface exudates of 34 cultivars

\begin{tabular}{lc}
\hline Cultivar/selection & TOC $^{\mathrm{a}}$ \\
\hline Highly sensitive & \\
Baroque 11-8-58 & $83.5 \pm 23.7$ \\
Flame Seedless & $97.2 \pm 11.9$ \\
A61-16 & $77.2 \pm 42.0$ \\
B1479-1 & $225.8 \pm 114.2$ \\
C89-44 & $50.9 \pm 10.4$ \\
Autumn Royal(A97-68) & $217.8 \pm 84.7$ \\
Ruby Seedless & $195.8 \pm 17.4$ \\
Queen & $97.7 \pm 18.9$ \\
B34-82 & $171.4 \pm 26.8$ \\
Autumn Seedless & $164.1 \pm 16.1$ \\
Dabouki & $64.4 \pm 24.7$ \\
Princess (C45-59) & $94.0 \pm 22.7$ \\
Red Roumi & $72.4 \pm 7.9$ \\
B37-41 & $24.8 \pm 19.7$ \\
Seibel 8229 & $249.9 \pm 110.4$ \\
Slightly resistant & \\
Red Globe & $42.4 \pm 4.9$ \\
C63-119 & $42.0 \pm 18.2$ \\
Golden Muscat & $365.9 \pm 153.3$ \\
Sultanina Marble & $338.5 \pm 177.3$ \\
Crimson Seedless & $191.0 \pm 21.4$ \\
Rhazaki de Crete & $300.1 \pm 23.9$ \\
Moderately resistant & \\
Autumn Black & $92.7 \pm 38.0$ \\
Seyve Villard 20-365 & $191.4 \pm 73.2$ \\
Emperor & $126.1 \pm 20.3$ \\
N.Y.36661 & $189.6 \pm 36.8$ \\
Highly resistant & \\
Niagara & $132.3 \pm 56.0$ \\
Seyve Villard 12-375 & $17.0 \pm 21.3$ \\
Bloodworth 81-107-11 & $123.6 \pm 51.1$ \\
B36-55 & $253.6 \pm 26.4$ \\
Last Rose & $100.7 \pm 12.5$ \\
Urbana & $72.4 \pm 21.8$ \\
Niabell & $116.0 \pm 43.7$ \\
Fredonia & $85.9 \pm 5.0$ \\
Muscat Angel & $40.5 \pm 10.0$ \\
\hline Expressed in mitograms & \\
\hline
\end{tabular}

${ }^{a}$ Expressed in micrograms of TOC per square centimeter of berry surface \pm standard deviation. vinifera, thicker berry cuticle was associated with increased resistance to B. cinerea (26). Commenil et al. (10) suggested that a 2.5 -fold decrease in cuticular matrix weight of grape berries between the immature and harvest stages was correlated with an increase in susceptibility to $B$. cinerea. We found that resistance of berries to $B$. cinerea increased with increase in thickness and number of epidermal and hypodermal cell layers. This result is supported by the findings of Karadimtcheva (26) and Sarig et al. (47). Sarig et al. (47) found that skin thickness was correlated with resistance, but suggested that fungal invasion was related more to cell density in the skin than to its absolute thickness. They observed gibberellin applications (a standard practice in table grape culture to increase berry size) enlarged cells and caused an increase in the total thickness of epidermal and hypodermal cell layers, which increased the incidence of decay. Conversely, cytokinin applications increased cell division, which also caused

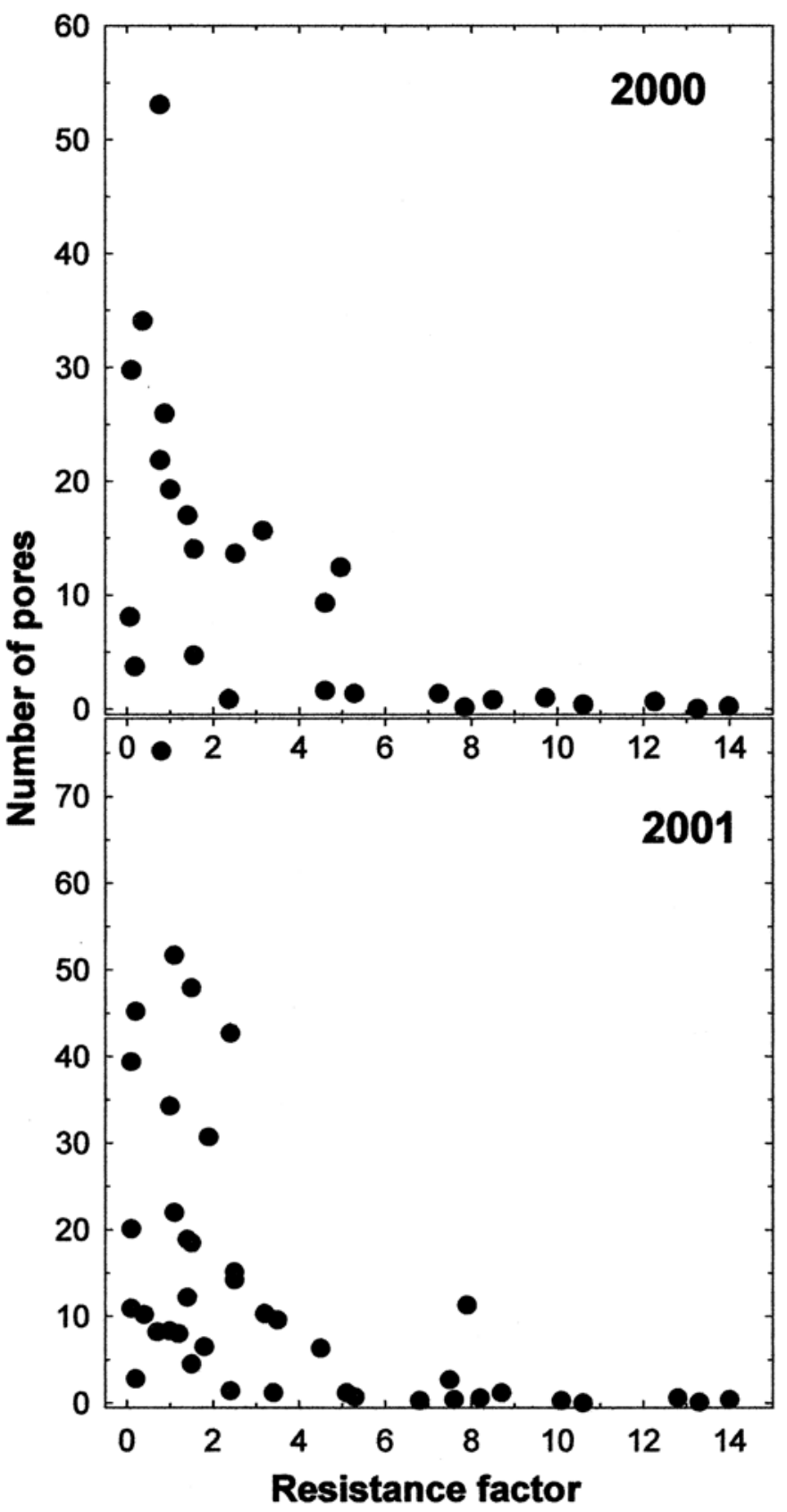

Fig. 1. Number of pores per $50 \mathrm{~mm}^{2}$ of grape berry surface in relation to the resistance to Botrytis cinerea infection. Resistance factor represents the number of times the test cultivar or selection is more or less resistant than susceptible cv. Thompson Seedless, whose resistant factor is 1 . 
an increase in the total thickness of epidermal and hypodermal cell layers, but resulted in a decreased decay incidence. Prudet et al. (41) reached similar conclusions. Once B. cinerea has penetrated the cuticle, it secretes enzymes during pathogenesis that penetrate host membranes, dissolve cell walls, and cause cell lysis, allowing the fungus to spread within the host tissue. The enzymes include aspartate proteinase, cellulase, polygalacturonase, pectin methylesterases, and $\beta$-glucosidase (51). Because most chemical response occurs in the skin cells, cultivars with a thicker skin and more skin cell layers, if genetically predisposed, may have a higher capacity to synthesize defense products and thus could respond more vigorously. We confirmed that there was a negative correlation between soluble solids content and resistance of berries to $B$. cinerea infections. With maturation, berry defense reactions in the tissue weaken and berries become more susceptible to infection $(35,45)$. Therefore, for mature berries, the cuticle may comprise a more important barrier to infection than epidermal cell features (35).

We expected to find correlation between berry exudates and increased surface porosity and between increased surface exudates and susceptibility to gray mold. Many researchers reported stimulatory effects of berry exudates on the germinating conidia and suggest nutrients, mainly sugars, dissolved in water on the surface of the berry could be a source of energy to germinating conidia $(5,7,17,28,37,52)$. Therefore, we analyzed aqueous extracts of berry surfaces to determine the total organic carbon content. We found no correlation between total organic carbon and susceptibility to gray mold or between total organic carbon and number of pores. Our results had considerable variation, indicating that loose pedicels or cracked berries might have elevated the total organic carbon content in some cases. Other researchers found that exudates did not have a large impact on infection $(22,35)$.

Many preformed defenses exist that are not morphological or anatomical (35). Tannin-like substances from the berry skin were capable of inhibiting hydroxystilbene-degrading laccase and polygalacturonase from $B$. cinerea $(35,53)$. Many researchers found a correlation between increased host resistance and a high phenolic compound content $(36,42,47)$. Goetz et al. (18) reported that all isolated constitutive berry phenols and catechols were active against $B$. cinerea laccases. They state that by inhibiting stilbene oxidase, Botrytis defense attenuated, leaving "safer ground" for the classical grape phytoalexins, resveratrol and pterostilbene. In our experiments, we did not find correlation between catechin content or total phenolics in the skin of mature berries and resistance to gray mold. Among sensitive entries, the total phenolic content was usually elevated by induction, whereas among highly resistant entries, the total phenolic content was little changed by induction.

PR proteins such as chitinase, grape osmotin, and $\beta-1,3-$ glucanase play an important role in plant defense mechanisms $(12,43,46)$. PR proteins are constitutive or can be induced by elicitors like salicylic acid, chitosan, methyl jasmonate, and an elicitor released from cell walls of $B$. cinerea $(12,44)$. However, the induction of PR proteins was not sufficient to stop $B$. cinerea spread in grapes $(4,43)$. Incidentally, PR proteins are not desirable products in wine, because they could cause hazing (34). We hypothesized that PR proteins might be detected as an increase in total protein content, but when we measured total protein content in noninoculated berry skins, we did not find correlation with resistance to gray mold. We did not quantify protein content in berries after inoculation, because the protein content of the inoculum and its enzymatic activity would have interfered with interpretation of the results.

The presence of stilbene phytoalexins in grape berries has been shown many times, but their role in resisting pathogens in vivo is less certain, although several authors have demonstrated correlation between resveratrol content and disease resistance $(13,29)$. The highest resveratrol content was detected in healthy berries surrounding infected area $(1,25)$. Pterostilbene, resveratrol, and viniferin are fungitoxic and induced by $B$. cinerea infection or UV light $(1,11,25,29,48)$. The capacity for resveratrol synthesis was considered as an early selection criterion to screen grapevines in vitro for resistance to gray mold $(23,49)$. Resveratrol content and production potential is highest in immature berries and drops sharply after veraison and during maturation, even in pathogentolerant American species $(24,45,48)$. Noninoculated berries produce stilbenes, but to a much lower extent than the inoculated berries (3). However, in mature berries, Adrian et al. (1) reported that the maximum trans-resveratrol concentrations occurred $48 \mathrm{~h}$ after UV elicitation and that the 2-day delay in resveratrol production was too late to stop $B$. cinerea infections. This was the induction period between inoculation and berry skin removal for

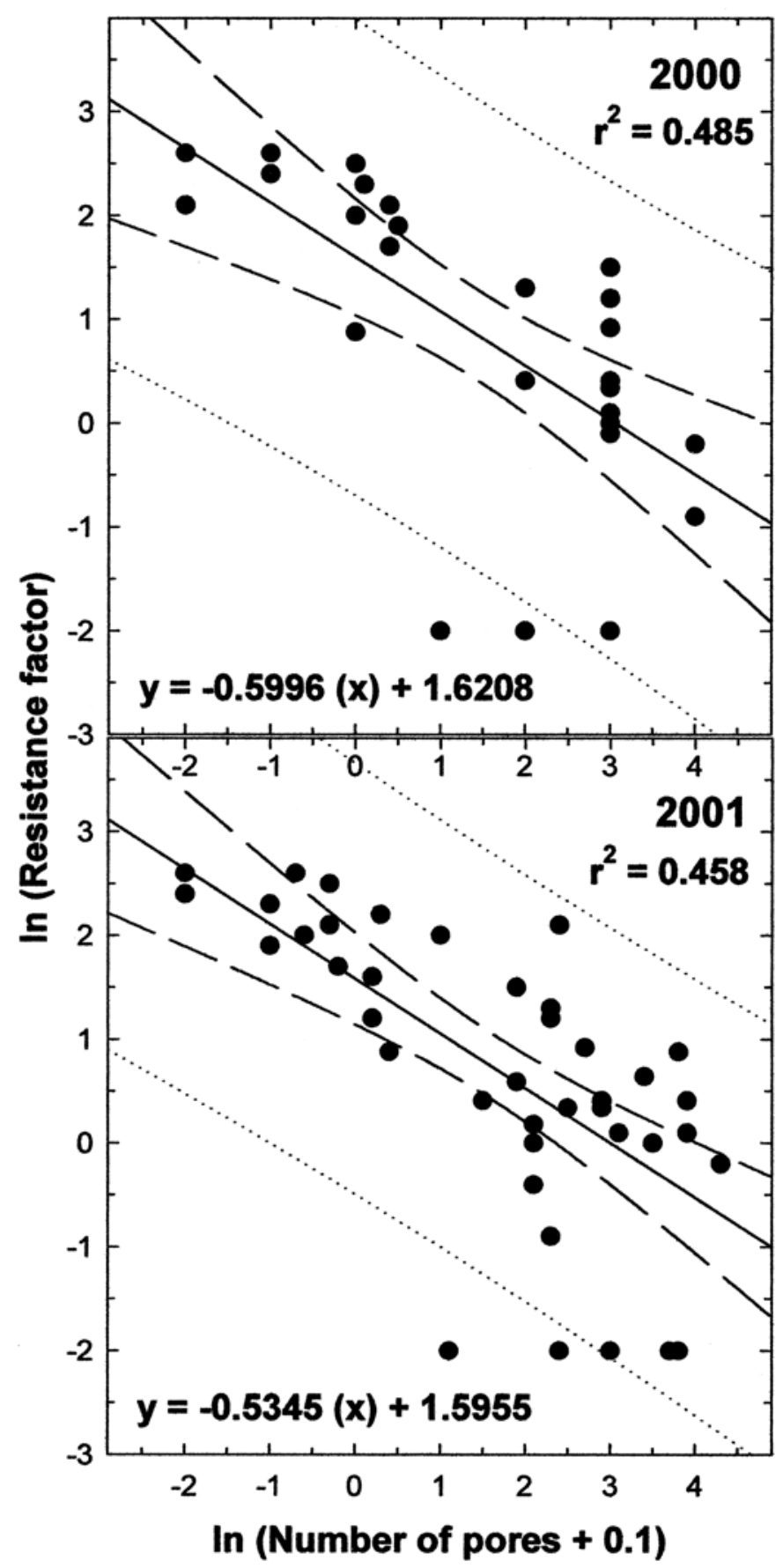

Fig. 2. Regression of the transformed values of the number of pores and resistance of grape berries to Botrytis cinerea infection. Dashed lines represent $95 \%$ confidence intervals on the prediction lines estimated from this data. Dotted lines represent confidence intervals on a prediction for a single future observation. 
resveratrol analysis in our experiments. Adrian et al. (1) found almost twice as much resveratrol synthesized in berries after UV elicitation as that found in berries surrounding $B$. cinerea-infected area. Apparently berries do not employ $100 \%$ of their resveratrol synthesis capacity in response to $B$. cinerea infection. In our experiments, trans- and cis-resveratrol were induced when grapes were inoculated with $B$. cinerea 2 days prior to sampling. In noninoculated berries, trans- and cis-resveratrol were detected in only 2 of 26 selections. After induction, they were detected in 13 of 26 selections; however, resveratrol content was not correlated with resistance. Highly resistant cultivars were $V$. rotundifolia, $V$. labrusca, or more complex hybrids. No resveratrol was induced in the skin of these highly resistant grapes after inoculation with $B$. cinerea. However, in V. vinifera cvs. Rhazaki de Crete, Emperor, and Autumn Black, all of which were slightly to moderately resistant to $B$. cinerea infection, the induced trans-resveratrol content was 9.6, 23.9, and $6.0 \mu \mathrm{g} / \mathrm{g}$ fresh weight, respectively, and much higher than that found in most sensitive cultivars. Similar values in induced berries were detected by Adrian et al. (1). Phytoalexins might not reach sufficient concentration to inhibit infection by B. cinerea $(25,39)$. Although Sbaghi et al. (49) found a significant correlation between resveratrol synthesis and gray mold resistance in grapevine leaves, they also found some contradictory cases in which resistance did not correlate with high resveratrol production. For example, susceptible cv. Carignan had a high resveratrol production capacity, whereas a highly resistant V. labrusca species had a moderate resveratrol production capacity. Dercks et al. (14) found that resveratrol production potential in the skin of $V$. labrusca and $V$. vinifera cv. Cabernet Sauvignon berries was similar. Pezet and Pont (39) suggest that, from bloom until maturity of berries, pterostilbene does not act as a single component but is rather a part of a chemical complex contributing to the natural resistance of grapes to $B$. cinerea because of the very low concentrations measured in grape berries compared with in vitro concentrations lethal to $B$. cinerea. Another important aspect that may diminish the importance of stilbenes in relation to pathogen resistance is that laccase produced by $B$. cinerea can detoxify stilbene phytoalexins rapidly (40,51). The final resistance is the result of the balance between the ability of the plant to produce phytoalexins and the ability of fungus to overcome this by producing stilbene oxidase (48).

A number of attributes of the grape berry may be involved in protection from fungal attack; only when all attributes are at low levels of expression is the berry susceptible to infection (47). We found that the very susceptible 'Ruby Seedless', C94-71, and A61-16 had thin cuticles, little wax, and numerous surface pores. Susceptible B37-41 had an intermediate amount of wax, low cuticle content, few cell layers in the skin, and very few pores. Moderately resistant 'Autumn Black' had a moderately thick cuticle, little wax, and few pores on the berry surface compared with the susceptible cultivars. The slightly more resistant 'Emperor' had little wax, very thick cuticle and skin, and few pores, whereas the similarly resistant N.Y. 36661 had average cuticle and wax but very few pores. All highly resistant entries had higher cuticle and wax contents and few or no pores. There were a few exceptions, such as cv. Queen, which had average cuticle and wax contents, fairly thick skin, and very low porosity, but was highly susceptible to infection. This result suggests that there may not be common mechanisms of resistance shared among all the entries and that some factors that we did not evaluate may be important.

Although we did not find a correlation between cluster density and resistance to gray mold, cluster density indirectly influenced other important attributes. Increased cluster density resulted in significantly lower cuticle content. In addition, increased cluster density positively correlated with number of pores. Vail and Marois (53) reported that the cultivars most severely affected by Botrytis bunch rot in the vineyard had the tightest clusters. In tight clusters, especially on the spots where berries touch each other, the cuticle was thinner and the wax content was reduced. Percival et al. (38) found a significant difference in wax and cuticle contents between the contact and noncontact regions within the cluster. In the contact region, the wax layer was less dense and lacked a platelet structure and had less cuticle $(33,38)$. When contact and noncontact surfaces of berries were inoculated, the contact surfaces had a higher proportion of infection than noncontact surfaces (33). Furthermore, tight clusters provide favorable humid microclimate for conidia to germinate $(33,53)$. Another issue with tight clusters is that pedicels could become loose, providing additional wounds and entry sites for the fungus (22).

Sarig et al. (47) suggested that the loose attachment between berry and pedicel, seen under the microscope as a wide or narrow area of cleavage, may facilitate $B$. cinerea colonization and infection. An acute angle of the pedicel and berry can contribute to disease development because it provides a location for spore accumulation and germination. In our work, loose pedicels might have played a role in the susceptibility of B1479-1 to infection because of its relatively high organic compound content in aqueous extracts from the berry surface, despite the low porosity, suggesting the organic compounds from the berry might have come from exposed pedicel area. Another important issue is that tight clusters dry at slower rates than loose clusters (53), providing a more humid and favorable microclimate for $B$. cinerea.

We agree that resistance of grape berries to $B$. cinerea infection is the result of many combined attributes and cannot be ascribed to a single feature $(22,23,35,47)$. However, in our work, we found that only anatomical features (cuticle and wax contents, number of pores on the berry, and number and thickness of skin cell layers) of berries were associated with resistance to gray mold. Highly resistant entries, with few exceptions, had few or no pores. Therefore, the prevention of infection by the properties of physical barriers was more important than the response by induced or constitutive antifungal compounds.

Because no phytoalexins or phenolics were induced in the skin of very resistant cultivars (none of which were $V$. vinifera), we assume that the low number of pores, thick cuticle, high wax content, and thick epidermis and external hypodermis with numerous cell layers were barriers sufficient to make them resistant to infection. To what extent resistance is related solely to the physical properties, and what portion is related to chemical characteristics of these barriers, not presently identified, is yet to be investigated. Because resistant selections were not infected, the presence of the pathogen was probably never detected, so phytoalexin or phenolic elicitation did not occur. However, if infection did occur, some form of induced chemical resistance could contribute to the resistance of grapes to infection.

\section{ACKNOWLEDGMENTS}

Financial support was provided by the California Table Grape Commission. We thank D. Margosan and J. Aiyabei for assistance with microscopy and image analysis, F. Ryan for help with phenolic and protein content determinations, S. Kupina of Canandaigua Wine in Madera, CA, for help with high-performance liquid chromatography analysis, and B. Teviotdale for critical review of the manuscript.

\section{LITERATURE CITED}

1. Adrian, M., Jeandet, P., Douillet-Breuil, A. C., Tesson, L., and Bessis, R. 2000. Stilbene content of mature Vitis vinifera berries in response to UVC elicitation. J. Agric. Food Chem. 48:6103-6105.

2. Baker, C. J., and Bateman, D. F. 1978. Cutin degradation by plant pathogenic fungi. Phytopathology 68:1577-1584.

3. Bavaresco, L., Petegolli, D., Cantu, E., Fregoni, M., Chiusa, G., and Trevisan, M. 1997. Elicitation and accumulation of stilbene phytoalexins in grapevine berries infected by Botrytis cinerea. Vitis 36:77-83.

4. Bezier, A., Lambert, B., and Baillieul, F. 2002. Study of defense-related gene expression in grapevine leaves and berries infected with Botrytis cinerea. Eur. J. Plant Pathol. 108:111-120. 
5. Blaich, R., Stein, U., and Wind, R. 1984. Perforationen in der Cuticula von Weinbeeren als morphologischer Faktor der Botrytisresistenz. Vitis 23:242-256.

6. Børve, J., Sekse, L., and Stensvand, A. 2000. Cuticular fractures promote postharvest fruit rot in sweet cherries. Plant Dis. 84:1180-1184.

7. Bulit, J., and Dubos, D. 1988. Botrytis bunch rot and blight. Pages 13-15 in: Compendium of Grape Diseases. The American Phytopathological Society, St. Paul, MN.

8. Cappellini, R. A., Ceponis, M. J., and Lightner, G. W. 1986. Disorders in table grape shipments to the New York market, 1972-1984. Plant Dis. 70:1075-1079.

9. Coertze, S., and Holz, G. 1999. Surface colonization, penetration, and lesion formation on grapes inoculated fresh or after cold storage with single airborne conidia of Botrytis cinerea. Plant Dis. 83:917-924.

10. Commenil, P., Brunet, L., and Audran, J. C. 1997. The development of the grape berry cuticle in relation to susceptibility to bunch rot disease. J. Exp. Bot. 48:1599-1607.

11. Creasy, L. L., and Coffee, M. 1988. Phytoalexin production potential of grape berries. J. Am. Soc. Hortic. Sci. 113:230-234.

12. Derckel, J.-P., Audran, J.-C., Haye, B., Lambert, B., and Legendre, L. 1998. Characterization, induction by wounding, and salicylic acid, and activity against Botrytis cinerea of chitinases and beta-1,3-glucanases of ripening grape berries. Physiol. Plant 104:56-64.

13. Dercks, W., and Creasy, L. L. 1989. The significance of stilbene phytoalexins in the Plasmopara viticola-grapevine interaction. Physiol. Mol. Plant Pathol. 34:189-202.

14. Dercks, W., Creasy, L. L., and Luczka-Bayles, C. J. 1995. Stilbene phytoalexins and disease resistance in Vitis. Pages 287-315 in: Handbook of Phytoalexin Metabolism and Action. Marcel Dekker, New York.

15. Eibach, R. 1994. Defense mechanisms of the grapevine to fungus disease. Am. Vineyard 1:8-10.

16. Fermin-Muñoz, G. A. 2000. Biotechnology: A new era for plant pathology and plant protection. Enhancing a plant's resistance with genes from the plant kingdom. APSnet Feature Story. Online. Published by The American Phytopathological Society, St. Paul, MN.

17. Fourie, J. F., and Holz, G. 1998. Effects of fruit and pollen exudates on growth of Botrytis cinerea and infection of plum and nectarine fruit. Plant Dis. 82:165-170.

18. Goetz, G., Fkyerat, A., Metais, N., Kunz, M., Tabacchi, R., Pezet, R., and Pont, V. 1999. Resistance factors to grey mould in grape berries: Identification of some phenolics inhibitors of Botrytis cinerea stilbene oxidase. Phytochemistry 5:759-767.

19. Hain, R., Reif, H.-J., Krause, E., Langebartels, R., Kindl, H., Vornam, B., Wiese, W., Schmelzer, E., Schreier, P. H., Stocker, R. H., and Stenzel, K. 1993. Disease resistance results from foreign phytoalexin expression in a novel plant. Nature 361:153-156.

20. Hill, G. K., Stellwaag-Kittler, F., Huth, G. T., and Schlosser, E. 1981. Resistance of grapes in different developmental stages to Botrytis cinerea. J. Phytopathol. Z. 102:328-338.

21. Holloway, P. J. 1969. Chemistry of leaf waxes in relation to wetting. J. Sci. Food Agric. 20:124-128.

22. Holz, G. 2001. The occurrence and control of Botrytis cinerea (Grey Mould) in grapes: A South African perspective. Wynboer: A Technical Guide for Wine Producers. Online publication. Sponsored by WineLand.

23. Jeandet, P., and Bessis, R. 1989. Account on morphological and biochemical mechanisms of vine-Botrytis interaction. Bull. de O.I.V. 703-704.

24. Jeandet, P., Bessis, R., and Gautheron, B. 1991. The production of resveratrol $\left(3,5,4^{\prime}\right.$-trihydroxystilbene) by grape berries in different developmental stages. Am. J. Enol. Vitic. 42:41-46.

25. Jeandet, P., Bessis, R., Sbaghi, M., and Meunier, P. 1995. Production of the phytoalexin resveratrol by grapes as a response to Botrytis attack under natural conditions. J. Phytopathol. 143:135-139.

26. Karadimtcheva, B. 1981. Characteristics of the anatomical structure of the grape skin in relation to resistance to grey mold. Gradinar. Lozar. Nauka 18:94-99.

27. Keen, N. T. 1999. Plant disease resistance: Progress in basic understanding and practical application. Adv. Bot. Res. 30:292-328.

28. Kosuge, T., and Hewitt, W. B. 1964. Exudates of grape berries and their effect on germination of conidia of Botrytis cinerea. Phytopathology 54:167-172.

29. Langcake, P., and McCarthy, W. V. 1979. The relationship of resveratrol production to infection of grapevine leaves by Botrytis cinerea. Vitis 18:244-253.

30. Liswidowati, F. M., Hohmann, F., Schiver, B., and Kindl, H. 1991. Induction of stilbene synthase by Botrytis cinerea in cultured grapevine cells. Planta 183:307-314.
31. Luvisi, D., Shorey, H., Smilanick, J. L., Thompson, J., Gump, B. H., and Knutson, J. 1992. Sulfur dioxide fumigation of table grapes. Univ. Calif. Div. Agric. Nat. Resour. Bull. 1932.

32. Marois, J. J., Bledsoe, A. M., and Bettiga, L. J. 1992. Bunch rots. Pages 64-70 in: Grape Pest Management. 2nd ed. Univ. Calif. Div. Agric. Nat. Resour. Publ. 3343.

33. Marois, J. J., Nelson, J. K., Morrison, J. C., Lile, L. S., and Bledsoe, A. M. 1986. The influence of berry contact within grape clusters on the development of Botrytis cinerea and epicuticular wax. Am. J. Enol. Viticult. 37:293-296.

34. Mazhar, H., Basha, S. M., and Lu, J. 2002. Variation in berry protein composition of muscadine cultivars. Am. J. Enol. Vitic. 53:87-91.

35. Nair, N. G., and Hill, G. K. 1992. Bunch rot of grapes caused by Botrytis cinerea. Pages 147-169 in: Plant Diseases of International Importance. J. Kumar, H. S. Chaube, U. S. Singh, and A. N. Mukhopadhyay, eds. Prentice Hall, Englewood Cliffs, NJ.

36. Orlando, R., Magro, P., and Rugini, E. 1997. Pectic enzymes as a selective pressure tool for in vitro recovery of strawberry plants with fungal disease resistance. Plant Cell Rep. 16:272-276.

37. Padgett, M., and Morrison, J. C. 1990. Changes in grape berry exudates during fruit development and their effect on mycelial growth of Botrytis cinerea. J. Am. Soc. Hortic. Sci. 115:269-273.

38. Percival, D. C., Sullivan, J. A., and Fisher, K. H. 1993. Effect of cluster exposure, berry contact and cultivar on cuticular membrane formation and occurrence of bunch rot (Botrytis cinerea PERS.: FR.) with 3 Vitis vinifera $\mathrm{L}$. cultivars. Vitis 32:87-97.

39. Pezet, R., and Pont, V. 1988. Identification of pterostilbene in grape berries of Vitis vinifera. Plant Physiol. Biochem. 26:603-607.

40. Pezet, R., Pont, V., and Hoang-Van, K. 1991. Evidence for oxidative detoxification of pterostilbene and resveratrol by a laccase-like stilbene oxidase produced by Botrytis cinerea. Physiol. Mol. Plant Pathol. 39:441-450.

41. Prudet, S., Dubos, B., and Le Menn, R. 1992. Some characteristics of resistance of grape berries to grey mold caused by Botrytis cinerea. Pages 99-103 in: Recent Advances in Botrytis Research. K. Verheff, N. E. Malathrakis, and B. Williamson, eds. Pudoc Scientific Publishers, Wageningen, the Netherlands.

42. Prusky, D., and Keen, N. T. 1993. Involvement of preformed antifungal compounds in the resistance of subtropical fruits to fungal decay. Plant Dis. 77:114-119.

43. Renault, A. S., Deloire, A., Letinois, I., Kraeva, E., Tesniere, C., Ageorges, A., Redon, C., and Bierne, J. 2000. B-1,3-Glucanase gene expression in grapevine leaves as a response to infection with Botrytis cinerea. Am. J. Enol. Vitic. 51:81-87.

44. Repka, V. 2001. Elicitor-stimulated induction of defense mechanisms and defense gene activation in grapevine cell suspension cultures. Biol. Plant. 44:555-565.

45. Riberau-Gayon, P., Dubordieu, D., Doneche, B., and Lonvaud, A. 2000. Handbook of Enology. Vol. 1. The Microbiology of Wine and Vinifications. John Wiley \& Sons, New York.

46. Salzman, R. A., Tikhonova, I., Bordelon, B. P., Hasegawa, P. M., and Bressan, R. A. 1998. Coordinate accumulation of antifungal proteins and hexoses constitutes a developmentally controlled defense response during fruit ripening in grape. Plant Physiol. 117:465-472.

47. Sarig, P., Zutkhi, Y., Lisker, N., Shkelerman, Y., and Ben-Arie, R. 1998. Natural and induced resistance of table grapes to bunch rots. Acta Hortic. 464:65-70

48. Sarig, P., Zutkhi, Y., Monjauze, A., Lisker, N., and Ben-Arie, R. 1997. Phytoalexin elicitation in grape berries and their susceptibility to Rhyzopus stolonifer. Physiol. Mol. Plant Pathol. 50:337-347.

49. Sbaghi, M., Jeandet, R., Faivre, B., Bessis, R., and Fournioux, J. C. 1995. Development of methods using phytoalexin (resveratrol) assessment as a selection criterion to screen grapevine in vitro cultures for resistance to grey mould (Botrytis cinerea). Euphytica 86:41-47.

50. Singelton, V. L. 1988. Wine phenols. Pages 173-218 in: Wine Analysis. H. F. Linsken and J. F. Jackson, eds. Springer-Verlag, Berlin.

51. Staples, R. C., and Mayer, A. M. 1995. Putative virulence factors of Botrytis cinerea acting as a wound pathogen. FEMS Microbiol. Lett. 134:1-7.

52. Urbasch, I. 1985. Dedifferenzierung der appressorien von Botrytis cinerea Pers. unter bildung von mikrokonidien-Relation zur Rezistenz von Lycopersicon spp. gegen B. cinerea. Phytopathol. Z. 113:348-358.

53. Vail, M. E., and Marois, J. J. 1991. Grape cluster architecture and the susceptibility of berries to Botrytis cinerea. Phytopathology 81: 188-191. 